Article

\title{
Selenium-Rich Ag-Au Mineralization at the Kremnica Au-Ag Epithermal Deposit, Slovak Republic
}

\author{
Martin Števko ${ }^{1,2, *}$, Jiří Sejkora ${ }^{1}$, Zdeněk Dolníček ${ }^{1}$ and Pavel Škácha ${ }^{1,3}$ \\ 1 Department of Mineralogy and Petrology, National Museum, Cirkusová 1740, Prague 9, \\ 19300 Horní Počernice, Czech Republic; jiri_sejkora@nm.cz (J.S.); zdenek_dolnicek@nm.cz (Z.D.); \\ skachap@seznam.cz (P.S.) \\ 2 UK Mining Ventures Ltd., No. 1, The Old Coach Yard, East Coker; Somerset BA22 9HY, UK \\ 3 Mining Museum Příbram, Hynka Kličky Place 293, Př́bram VI, 26101 Březové Hory, Czech Republic \\ * Correspondence: msminerals@gmail.com; Tel.: +421-915-810-274
}

Received: 19 October 2018; Accepted: 1 December 2018; Published: 4 December 2018

\begin{abstract}
Selenium-rich Au-Ag mineralization has been discovered in the Kremnica ore district, central Slovakia. The mineralization is hosted by a single quartz-dolomite vein hosted by Neogene propyllitized andesites of the Kremnica stratovolcano. Ore mineralogy and crystal chemistry of individual ore minerals have been studied here. The early base-metal ore mineralization composed of pyrite, sphalerite, and chalcopyrite lacks selenium, whereas the superimposed $\mathrm{Au}-\mathrm{Ag}$ paragenesis is Se-enriched. The Au-Ag alloys, uytenbogaardtite, minerals of the galena-clausthalite series, acanthite-naumannite series, diaphorite, miargyrite, pyrargyrite-proustite, polybasite group, minerals of the tetrahedrite group and andorite branch (andorite IV, andorite VI, Ag-excess fizélyite), freieslebenite, and rare $\mathrm{Pb}-\mathrm{Sb}$ sulphosalts (scaiinite, robinsonite, plagionite) have been identified here. Besides selenides, the most Se-enriched phases are miargyrite, proustite-pyrargyrite, and polybasite-pearceite, whose Se contents are among the highest reported worldwide. In addition, one new phase has been found, corresponding to a Se-analogue of pearceite containing 2.08-3.54 apfu Se. The style of mineralization, paragenetic situation, and chemical trends observed in individual minerals are comparable to those of $\mathrm{Au}-\mathrm{Ag}$ low-sulphidation epithermal $\mathrm{Au}-\mathrm{Ag}$ mineralizations of the Kremnica and neighboring Štiavnica and Hodruša-Hámre ore districts. However, the pronounced enrichment in selenium is a specific feature of the studied vein only.
\end{abstract}

Keywords: Au-Ag low-sulphidation epithermal mineralization; Kremnica; gold; selenides; Ag sulphoslats

\section{Introduction}

The ore mineralizations containing selenides or Se-enriched minerals are rather rare in the territory of the Slovak part of the Western Carpathians. A Bi-Se-Te mineralization represented mainly by telluronevskite and vihorlatite is relatively abundant in bodies of metasomatites and secondary quartzites near Poruba pod Vihorlatom, Vihorlat Mountains. [1-3]. Minor amounts of selenides (clausthalite, bohdanowitzite, naumannite, laitakarite, and ikunolite) as well as Se-bearing bournonite, hedleyite, jamesonite, tetradymite, and tintinaite were described from the quartz-siderite-sulphidic veins near Dobšiná and Uhorná in the Gemeric Superunit [4-6]. Clausthalite has also been identified at the stratiform U-Mo deposit at Novoveská Huta [7]. Laitakarite together with Se-bearing galena and sulphosalts were described from the sulphidic mineralization at the Mútnik magnesite deposit near Hnúšt’a $[8,9]$. 
The Central Slovakia Volcanic Field hosts several famous Ag-Au epithermal vein-type deposits including Banská Štiavnica, Kremnica, Hodruša-Hámre, and Nová Baňa, which were important sources of precious as well as base metals in the past. The only known and very limited occurrence of selenides from the epithermal veins in this area was described by Jeleň [10], who identified microscopic aggregates of naumannite associated with Se-bearing galena and Se-bearing matildite from the deeper parts of the Špitaler vein in the Banská Štiavnica ore district. Mat'o and Háber [11], Mat'o [12], and Mat'o and Ragan [9] reported the presence of elevated amounts of selenium in galena, acanthite, and minerals of the polybasite group from the 1st vein system of the Kremnica Au-Ag deposit. This paper deals with a unique occurrence of selenides and Se-enriched Ag sulphosalts, which was recently discovered in the Václav-south adit, 1st vein system of the Kremnica Au-Ag epithermal deposit.

\section{Geological Setting}

The Kremnica Au-Ag epithermal deposit is located in the vicinity of the Kremnica town, in the northern part of the Central Slovakian Volcanic Field, which is represented by the remnants of a large andesite stratovolcano. This deposit was the most important gold producer in Slovakia, with overall production of 35 tons of gold.

The system of low-sulphidation epithermal veins with $\mathrm{Au}-\mathrm{Ag}-\mathrm{Sb}$ mineralization was developed on marginal faults in the eastern part of the Kremnica resurgent horst (Figure 1). The horst is built of Miocene pre-graben propylitised andesites accompanied at the depth by sub-volcanic intrusions of gabbrodiorite, diorite, diorite porphyry, and minor quartz-diorite porphyry [13]. The structure of the horst is dominated by N-S and NE-SW trending normal faults [14]. The two principal vein systems were distinguished at the Kremnica deposit [15-17]. The 1st vein system, which is located NW of the Kremnica town, is dominated by a first-order listric fault, intruded by rhyolite dikes. The mineralized fault dipping $50^{\circ}$ to $60^{\circ}$ gradually opens towards the surface to its maximum width of $80 \mathrm{~m}$ in the central part of the Šturec area. The total length of the 1st vein system is close to $6.5 \mathrm{~km}$ and the vertical extent of veins exceeds $1.2 \mathrm{~km}$ in the northern part of the system [18]. The 2nd vein system extends underneath the town of Kremnica and it is represented by a large-scale complementary vein system with 40 veins in the hanging wall of the listric fault. In contrast to the 1 st vein system, the veins are much shorter (less than $1.5 \mathrm{~km}$ ) and no more than $2 \mathrm{~m}$ wide [15]. The dominant gangue minerals at both vein systems are represented by banded and cavernous quartz with carbonates, mainly dolomite and calcite. According to Böhmer [15] and Mat'o [19] the vein filling was formed during the two main mineralization stages ( $\mathrm{Au}-\mathrm{Ag}$ stage and $\mathrm{Au}-\mathrm{Hg}-\mathrm{Sb}-\mathrm{As}$ stage) with six mineral associations. Pyrite, arsenopyrite, and gold (electrum) are the most frequent ore minerals of the Au-Ag stage, accompanied by minor galena, sphalerite, chalcopyrite, acanthite, proustite, pyrargyrite, polybasite, stephanite, miargyrite, and tetrahedrite. In the deeper parts of the 1 st vein system, the base-metal sulphides are more common and are accompanied by tellurides like altaite, goldfieldite, hessite, petzite, and stützite. Macroscopic gold (electrum) is much more common at the 2 nd vein system. The $\mathrm{Au}-\mathrm{Hg}-\mathrm{Sb}-\mathrm{As}$ stage includes quartz-carbonate and stibnite substage, with stibnite, pyrite, marcasite, and minor cinnabar as principal ore minerals $[11,12,15,17,19-21]$. Extensive wallrock alteration includes orthoclase var. adularia, quartz, illite/smectite, kaolinite, passing outwards into chlorite, smectite with disseminated pyrite and carbonates [22]. A recent fluid inclusion study and oxygen isotope data from the vein quartz showed that the northern part of the 1st vein system has the highest homogenization temperatures (Th) of fluid inclusions ( 250 to $270{ }^{\circ} \mathrm{C}$ ) and the average Th values decrease gradually towards the south. Fluids are predominantly of meteoric origin with low salinity ( 0.5 to $1.6 \mathrm{wt} \% \mathrm{NaCl}$ eq.). Two episodes of boiling of fluids at $240{ }^{\circ} \mathrm{C}$ and $205^{\circ} \mathrm{C}$ were documented at the central part of the 1st vein system (area of Šturec), indicating a long-living hydrothermal system with a syngenetic uplift of the Kremnica resurgent horst [17,23]. 


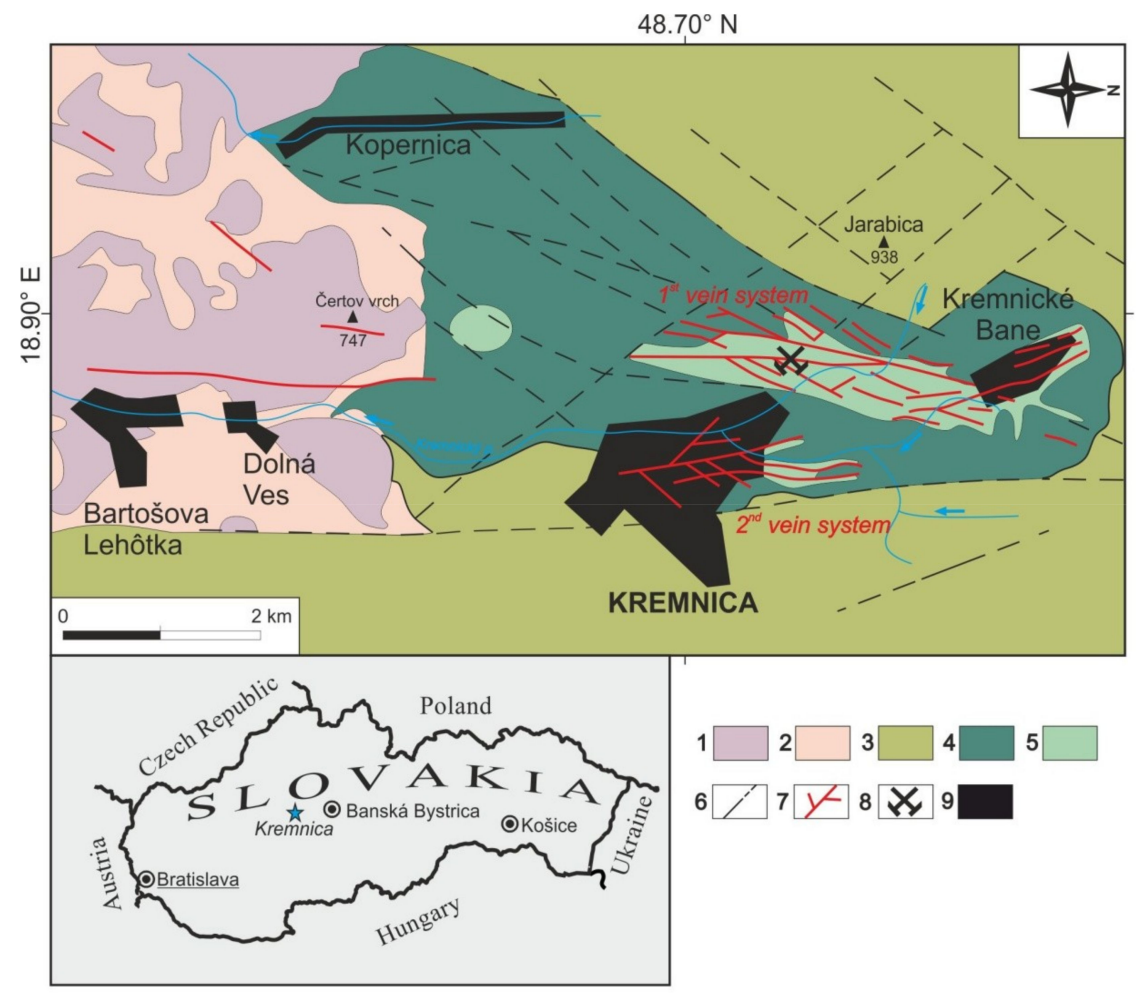

Figure 1. Geological map of the study area. Explanations: 1-rhyolite, 2-rhyolite tuffs, 3-Kremnica graben andesites, 4-pre-graben andesites, 5-hydrothermally altered rock, affected mostly by kaolinization and adularization, 6-faults, 7-epithermal veins, 8-position of the Václav-south adit, 9-villages and towns. Adapted with permission from Koděra and Lexa [17].

The samples studied were collected from the quartz-dolomite vein, situated at the hanging of the 1st stibnite vein in the crosscut P-102, Václav-south adit, in the central part of the 1st vein system (area of Šturec). The GPS coordinates of Václav-south adit are: $48^{\circ} 42^{\prime} 42.16^{\prime \prime} \mathrm{N}$ and $18^{\circ} 54^{\prime} 6.93^{\prime \prime} \mathrm{E}$. This thin (from 3 to $20 \mathrm{~cm}$ wide) NE-SW trending vein was explored in 1958 by short drive and exhibits brecciated to drusy structure, with white to grey cavernous or drusy quartz and yellow crystalline dolomite as principal minerals. Macroscopic aggregates of older common sulphides (sphalerite and pyrite) up to $5 \mathrm{~mm}$ as well as younger Ag-sulphosalts (mainly miargyrite, pyrargyrite, and proustite) up to $2 \mathrm{~mm}$ are locally scattered in both quartz and dolomite.

\section{Sampling and Analytical Methods}

The studied ore samples were collected in situ in the adit Václav-south from an unnamed quartz-dolomite vein located at the hanging of the 1st stibnite vein in the central part of the 1st vein system of the Kremnica Au-Ag deposit.

Samples for microscopy and following laboratory study were prepared as polished sections $2.54 \mathrm{~cm}$ in diameter, mounted in resin, and polished with diamond suspensions in the Diatech s.r.o. company, Prague, Czech Republic. The ore minerals and textures were studied in reflected light using a Nikon Eclipse ME600 polarizing microscope in the National Museum, Prague, Czech Republic.

The chemical analyses of individual minerals were performed using a Cameca SX100 electron microprobe (National Museum, Prague) operating in the wave-dispersive (WDS) mode ( $25 \mathrm{kV}, 10 \mathrm{nA}$, and 1-5 $\mu \mathrm{m}$ wide beam). The following standards and X-ray lines were used to minimize line overlaps: $\mathrm{Ag}(\mathrm{AgL} \alpha), \mathrm{Au}(\mathrm{AuM} \alpha), \mathrm{Bi}_{2} \mathrm{Se}_{3}(\mathrm{BiM} \beta), \mathrm{CdTe}(\mathrm{CdL} \alpha)$, chalcopyrite $(\mathrm{CuK} \alpha, \mathrm{SK} \alpha), \mathrm{FeS}_{2}$ $(\mathrm{FeK} \alpha)$, Ge $(\mathrm{GeL} \alpha)$, halite $(\mathrm{ClK} \alpha)$, $\operatorname{HgTe}(\operatorname{HgL} \alpha), \mathrm{Mn}(\mathrm{MnK} \alpha)$, NiAs $(\mathrm{AsL} \beta), \mathrm{PbS}(\mathrm{PbM} \alpha)$, PbSe ( $\mathrm{SeL} \beta)$, $\mathrm{PbTe}(\mathrm{TeL} \alpha), \mathrm{Sb}_{2} \mathrm{~S}_{3}(\mathrm{SbL} \alpha)$, and $\mathrm{ZnS}(\mathrm{ZnK} \alpha)$. Peak counting times were 20-30 s, and one-half of the peak time was used for each background. Contents of the above-listed elements, which are not 
included in the tables, were analyzed quantitatively, but their contents were below the detection limit (ca. 0.01-0.04 wt \% for individual elements). Raw intensities were converted to the concentrations of elements using automatic "PAP" matrix-correction software [24]. Tables containing the full data-set of collected WDS analyses (more than 1500 analytical points) are included as supplementary files for this paper.

\section{Mineralogy and Mineral Chemistry}

\subsection{Selenides}

Minerals of the clausthalite-galena series, $\mathbf{P b S e}-\mathbf{P b S}$, are frequent. They form irregular anhedral grains and aggregates up to $200 \mu \mathrm{m}$ in size (Figure 2a,b), which are often closely associated together with diaphorite, miargyrite, pyrargyrite-proustite, andorite, minerals of the polybasite and tetrahedrite group, and minor amounts of gold-silver alloy and acanthite.
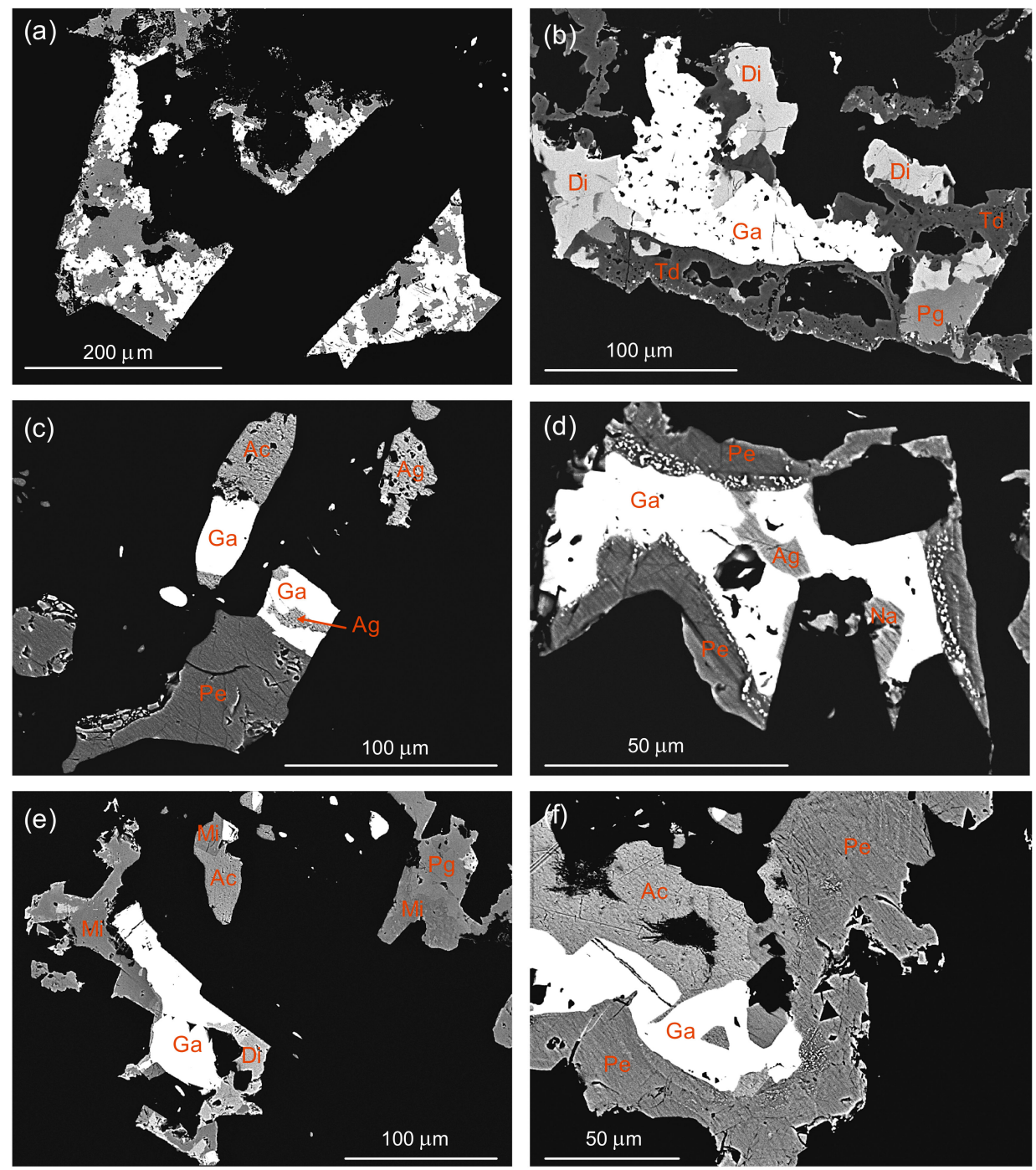

Figure 2. (a) Clausthalite (white) intergrown with Se-rich diaphorite (grey); (b) Se-rich galena (Ga) associated with diaphorite (Di), pyrargyrite $(\mathrm{Pg})$ and Ag-rich tetrahedrite $(\mathrm{Td})$; (c) aguilarite $(\mathrm{Ag})$ associated with Se-rich acanthite (Ac), galena (Ga) and Se-rich pearceite (Pe); (d) naumannite (Na) associated with aguilarite $(\mathrm{Ag})$, galena $(\mathrm{Ga})$, and pearceite $(\mathrm{Pe})$; (e) acanthite $(\mathrm{Ac})$ associated with galena $(\mathrm{Ga})$, pyrargyrite $(\mathrm{Pg})$, miargyrite $(\mathrm{Mi})$, and diaphorite (Di); (f) Se-rich acanthite (Ac) associated with pearceite $(\mathrm{Pe})$, and galena $(\mathrm{Ga})$; all back-scattered electron (BSE) images. 
During the study of chemical composition of minerals of the clausthalite-galena series (Table S1) we have observed only minor traces of $\mathrm{Cu}, \mathrm{Hg}, \mathrm{Fe}, \mathrm{Cd}, \mathrm{Sb}$, and Bi not exceeding $0.04 \mathrm{apfu}$. Somewhat higher are Ag contents, reaching up to 0.08 apfu and also interesting contents of $\mathrm{Cl}$ up to 0.01 apfu $(0.13 \mathrm{wt} \%)$ were determined. The range of SeS -1 substitution is limited (Figure 3), the highest Se content in clausthalite does not exceed $0.76 \mathrm{apfu}$. With regard to unlimited miscibility between clausthalite and galena observed in experimental studies [25-27] and also natural samples [28-32], the absence of next members to pure clausthalite in the studied samples is probably a result of lower value of $f \mathrm{Se}_{2}$ in the fluids with $f \mathrm{Se}_{2} / f \mathrm{~S}_{2}$ ratio close to unity $[33,34]$.

Naumannite, $\mathbf{A g}_{2} \mathrm{Se}$, and aguilarite, $\mathbf{A g}_{4} \mathrm{SeS}$, are rare and they occur as irregular elongated grains up to $30 \mu \mathrm{m}$ in size (Figure $2 \mathrm{c}, \mathrm{d}$ ) in association with acanthite, galena-clausthalite, and pearceite. Acanthite, $\mathbf{A g}_{2} \mathbf{S}$, is a bit more frequent as anhedral grains up to $120 \mu \mathrm{m}$ in size (Figure $2 \mathrm{e}, \mathrm{f}$ ) accompanied predominantly with miargyrite, galena-clausthalite, pyrargyrite-proustite, andorite, and minerals of the polybasite and tetrahedrite group and minerals of the gold-silver solid solution.

Nomenclature of mineral phases along the $\mathrm{Ag}_{2} \mathrm{~S}-\mathrm{Ag}_{2} \mathrm{Se}$ join was published by Bindi and Pingitore [35]. They suggest that two distinct solid solution series could exist: monoclinic "acanthite-type" series including aguilarite in the range $\mathrm{Ag}_{2} \mathrm{~S}-\mathrm{Ag}_{2} \mathrm{~S}_{0.4} \mathrm{Se}_{0.6}$, and an orthorhombic "naumannite-type" series between $\mathrm{Ag}_{2} \mathrm{~S}_{0.3} \mathrm{Se}_{0.7}-\mathrm{Ag}_{2} \mathrm{Se}$. The question is the status of members with Se contents in the range 0.60-0.70, which correspond to the two-phase (monoclinic and orthorhombic) field, which was described by Pingitore et al. [36] and Pal'yanova et al. [37]. There are two possible explanations: either presence of a metastable cubic high-temperature phase or mixture of two sub-microscopic phases formed during cooling of a homogenous cubic phase below $80{ }^{\circ} \mathrm{C}$ [38]. Natural minerals with compositions corresponding to this two-phase field were also reported [38,39].

During our study of chemical composition of mineral phases along the $\mathrm{Ag}_{2} \mathrm{~S}-\mathrm{Ag}_{2} \mathrm{Se}$ join (Table S2), the compositions related to acanthite and aguilarite, phases from the so-called two-phase field, as well as naumannite were observed (Figure 4). Acanthite contains selenium up to 0.28 apfu and aguilarite in the range 0.51-0.58 apfu (on the base of three atoms). Compositions of mineral phases of the two-phase field (0.67-0.70 apfu) are close to naumannite which has 0.71-0.90 apfu Se (Figure 4). In all studied phases, irregular traces of $\mathrm{Hg}, \mathrm{Cl}$, and $\mathrm{Te}$ (up to 0.02 apfu) were also found. The observed minor contents of $\mathrm{Fe}, \mathrm{Pb}, \mathrm{Zn}$, and $\mathrm{Cu}$ in some analyzed points were probably influenced by surrounding phases.

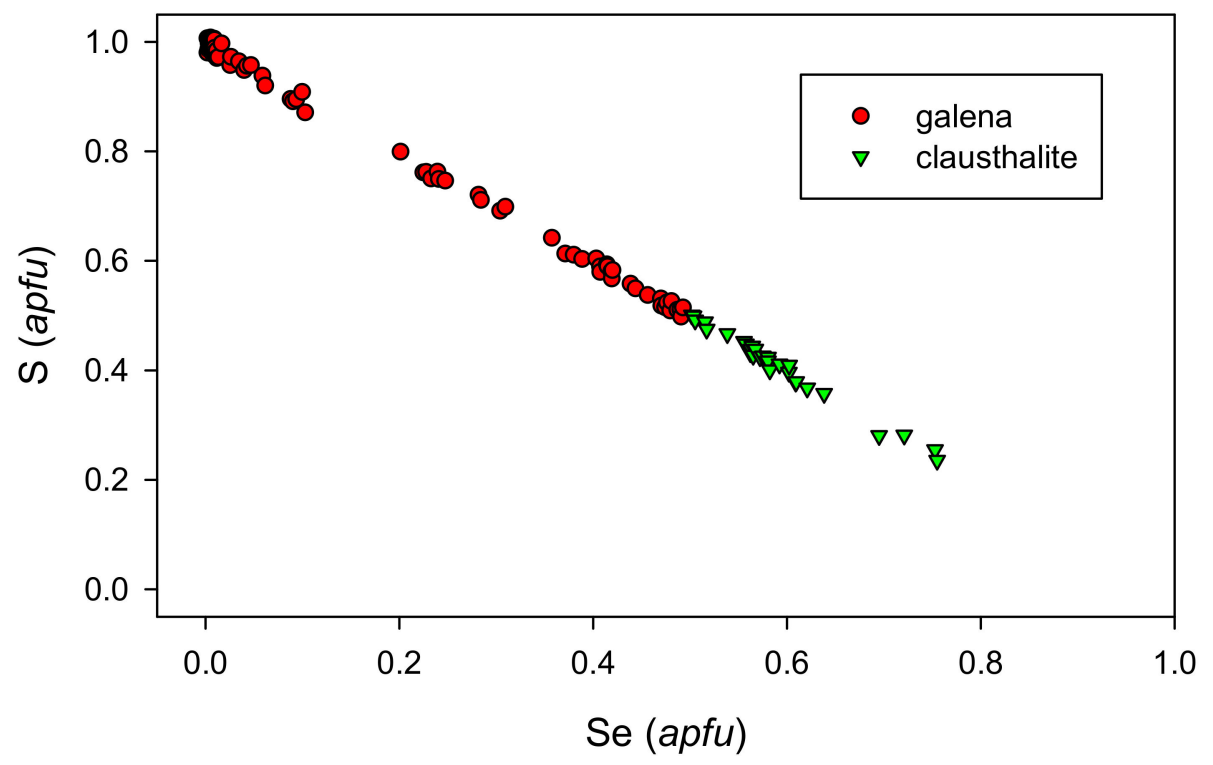

Figure 3. Graph of Se vs. S (apfu) for members of the clausthalite-galena series from the Kremnica deposit. 


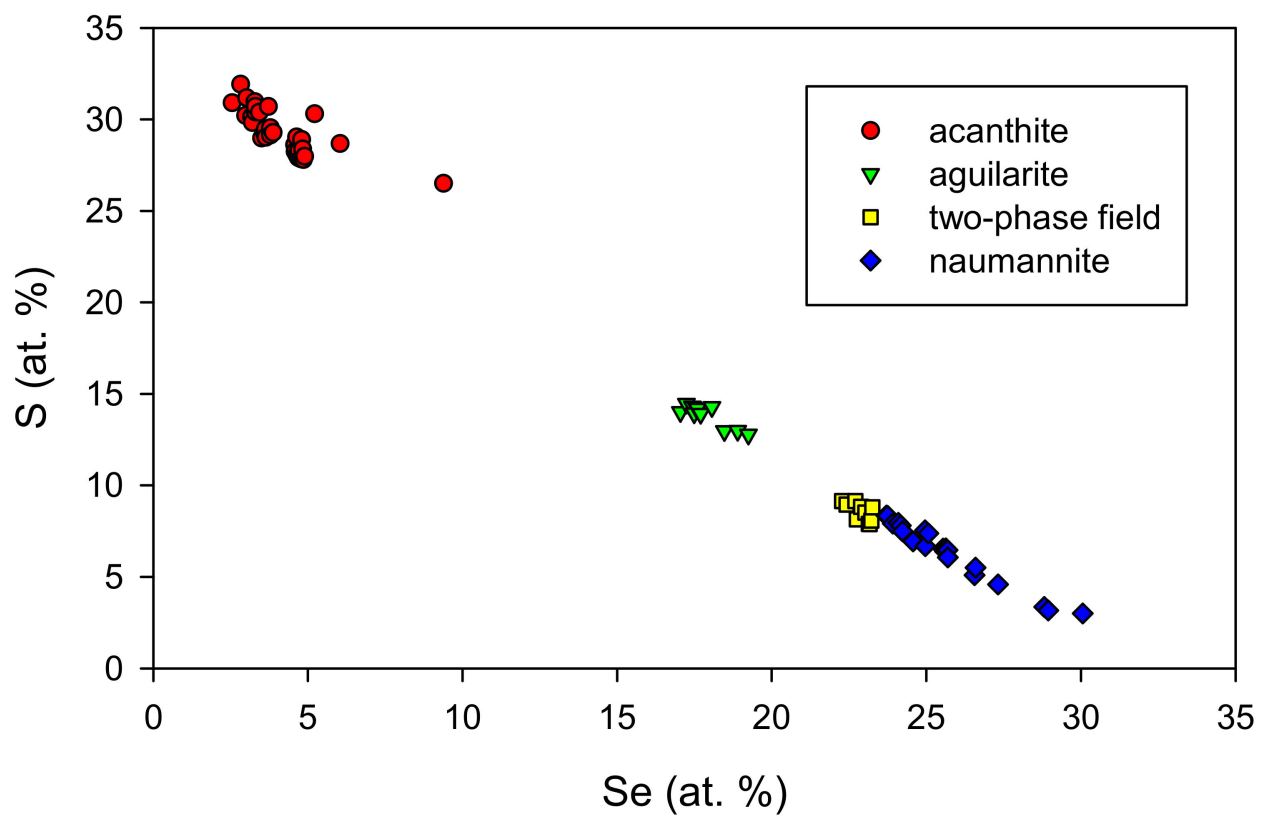

Figure 4. Graph of Se vs. S (at. \%) for mineral phases of the $\mathrm{Ag}_{2} \mathrm{~S}-\mathrm{Ag}_{2} \mathrm{Se}$ series from the Kremnica deposit.

\subsection{Au-Ag Minerals}

Minerals from the $\mathbf{A u}-\mathbf{A g}$ solid solution are infrequent and form anhedral grains up to $100 \mu \mathrm{m}$ in size (Figure 5), which often show strong irregular chemical zoning in back-scattered electron (BSE) images (Figure $5 b$ ). They are associated with acanthite, andorite, galena-clausthalite, diaphorite, pyrargyrite-proustite, and minerals of the polybasite and tetrahedrite group.

Highly variable chemical composition is typical (Table S3, Figure 6) ranging from silver with Au contents in the range 0.11-0.49 apfu, up to gold with Ag contents between 0.31 and 0.42 apfu. Both minerals are $\mathrm{Hg}$ free, and only insignificant traces of $\mathrm{Fe}, \mathrm{Cu}$, and $\mathrm{Cl}$ were identified.
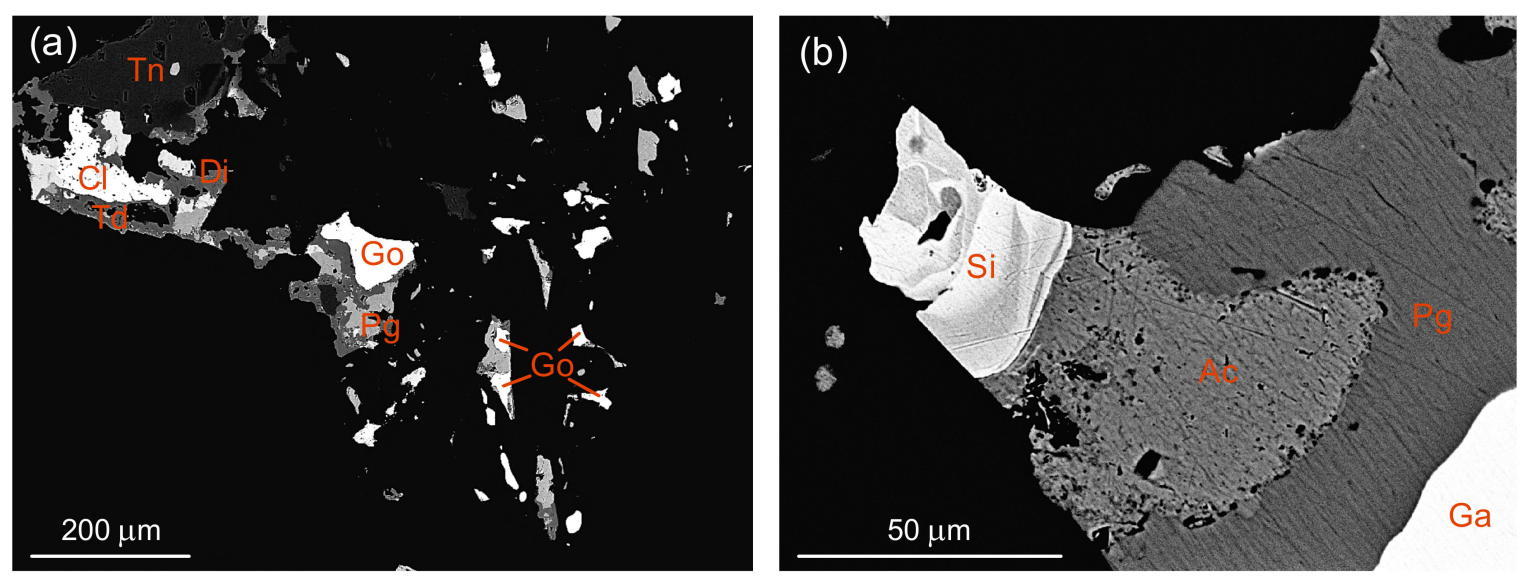

Figure 5. (a) Ag-rich gold (Go) in association with pyragyrite $(\mathrm{Pg})$, clausthalite $(\mathrm{Cl})$, diaphorite (Di), Ag-rich tetrahedrite (Td), and Ag-rich tennantite (Tn); (b) zoned silver (Si) with variable Au contents (18-57 wt \%) in association with Se-rich acanthite (Ac), pyrargyrite (Pg), and galena (Ga); both back-scattered electron (BSE) images. 


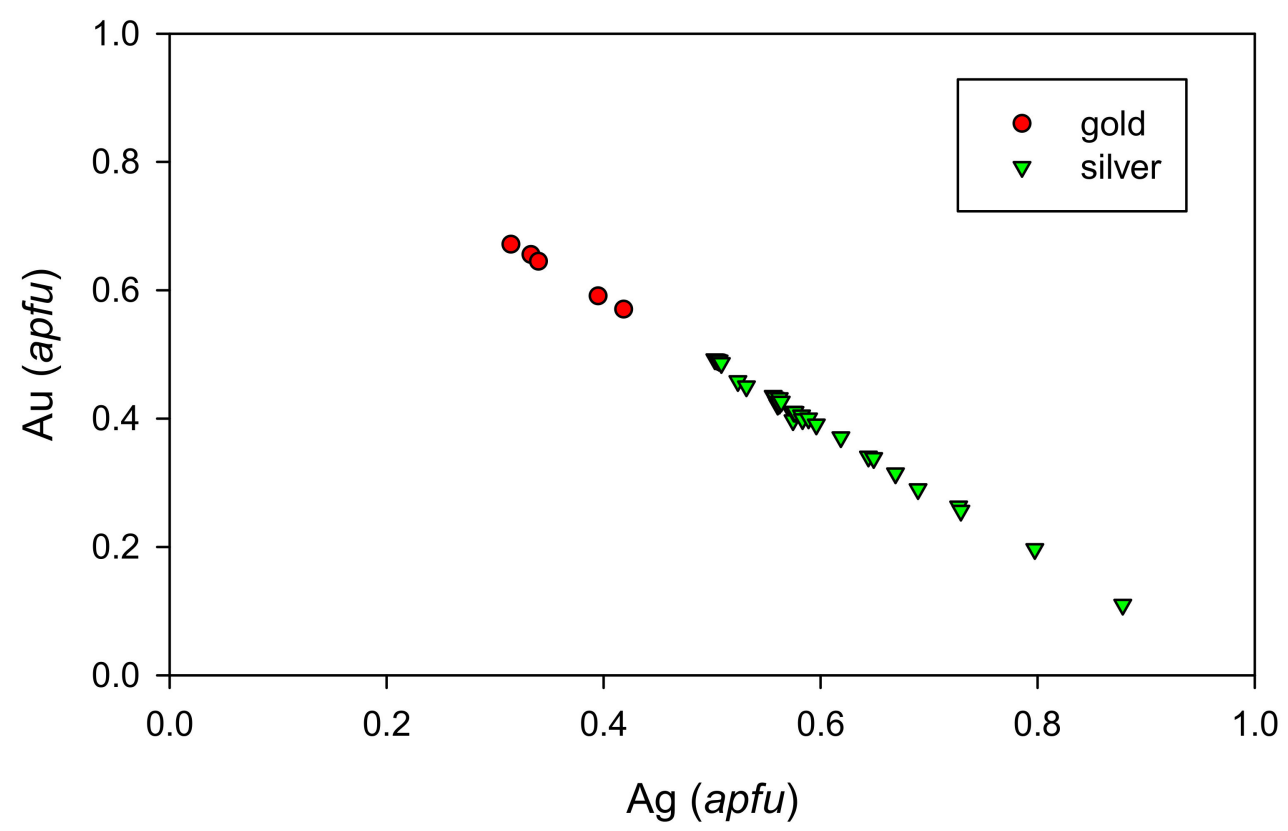

Figure 6. Graph of Ag vs. Au (apfu) for members of the Ag-Au solid solution from the Kremnica deposit.

Uytenbogaardtite, $\mathbf{A g}_{3} \mathbf{A u S}_{2}$, is found very rarely as single irregular grains only $13 \mu \mathrm{m}$ in size, which are closely associated with gold-silver alloy, miargyrite, and minerals of the tetrahedrite group. Its chemical composition (Table S4) is slightly different with regards to the ideal formula $\mathrm{Ag}_{3} \mathrm{AuS}_{2}$, especially by lower contents of $\mathrm{Au}$. This is most probably caused by some inhomogeneity of the studied grain, by its non-stoichiometry, or by its instability under the electron beam [40,41]. The determined selenium contents reached only up to $0.08 \mathrm{apfu}$, the observed minor contents of $\mathrm{Fe}, \mathrm{Pb}, \mathrm{Cu}$, and $\mathrm{Sb}$ are probably influenced by surrounding phases.

\subsection{Ag-Sb(-As) Sulphosalts}

Miargyrite, $\mathbf{A g S b S}_{2}$, is very common and occur as euhedral and anhedral grains and aggregate up to $2 \mathrm{~mm}$ in size (Figure 7), which are closely associated predominantly together with pyrargyrite-proustite, andorite, diaphorite, galena-clausthalite, and minerals of the tetrahedrite group. It often shows strong irregular chemical zoning in BSE images (Figure 7c,d).

For the chemical composition of miargyrite the significant range of $\mathrm{SeS}_{-1}$ substitution up to $0.75 \mathrm{apfu}$ is characteristic (Figure 8). Similar high selenium contents are reported for miargyrite from only two sites: Kutná Hora, Czech Republic (up to 0.62 apfu) [42] and Ailaoshan, China (up to 0.60 apfu) [43]. A natural sample from an unspecified locality in the USSR with contents of Se up to 1.34 apfu [44] was in fact a selenium analogue of miargyrite. Besides identified traces of $\mathrm{Pb}, \mathrm{Fe}, \mathrm{Zn}$, $\mathrm{Cu}$, and $\mathrm{Hg}$, contents of As in range up to 0.23 apfu were determined. The negative correlation of As with $\mathrm{Sb}$ (Figure 9) indicates the large extent of $\mathrm{AsSb}_{-1}$ substitution. According to experiments made by Ghosal and Sack [45], similar As contents in miargyrite occur only in the temperature range $200-350{ }^{\circ} \mathrm{C}$. The chemical analyses of miargyrite and corresponding empirical formulae are given in Table S5.

Minerals of the pyrargyrite-proustite series, $\mathrm{Ag}_{3} \mathrm{SbS}_{3}-\mathrm{Ag}_{3} \mathrm{AsS}_{3}$, are frequent. They form euhedral and anhedral grains and aggregates up to $2 \mathrm{~mm}$ in size, often with irregular chemical zoning in BSE photos (Figure 10). They are predominantly accompanied by miargyrite, andorite, diaphorite, galena-clausthalite, and minerals of the polybasite and tetrahedrite group. 

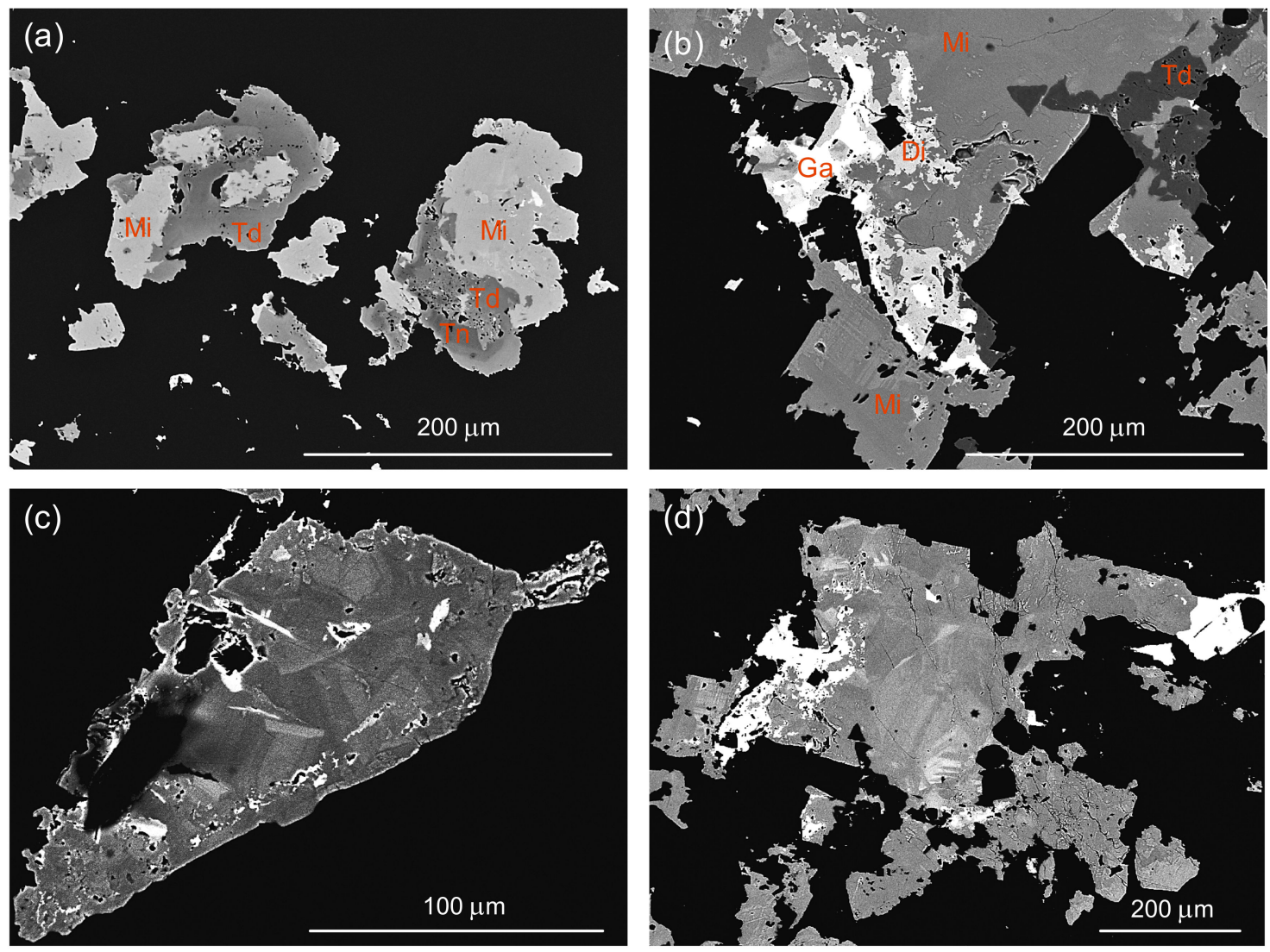

Figure 7. (a) Miargyrite (Mi) intergrown with Ag-rich tetrahedrite (Td) and tennantite (Tn); (b) Se-rich miargyrite (Mi) associated with diaphorite (Di), Ag-rich tetrahedrite (Td) and galena (Ga); (c) zonal miargyrite with variable Se contents; (d) zonal miargyrite with variable Se contents (grey) in association with Se-rich galena (white); all back-scattered electron (BSE) images.

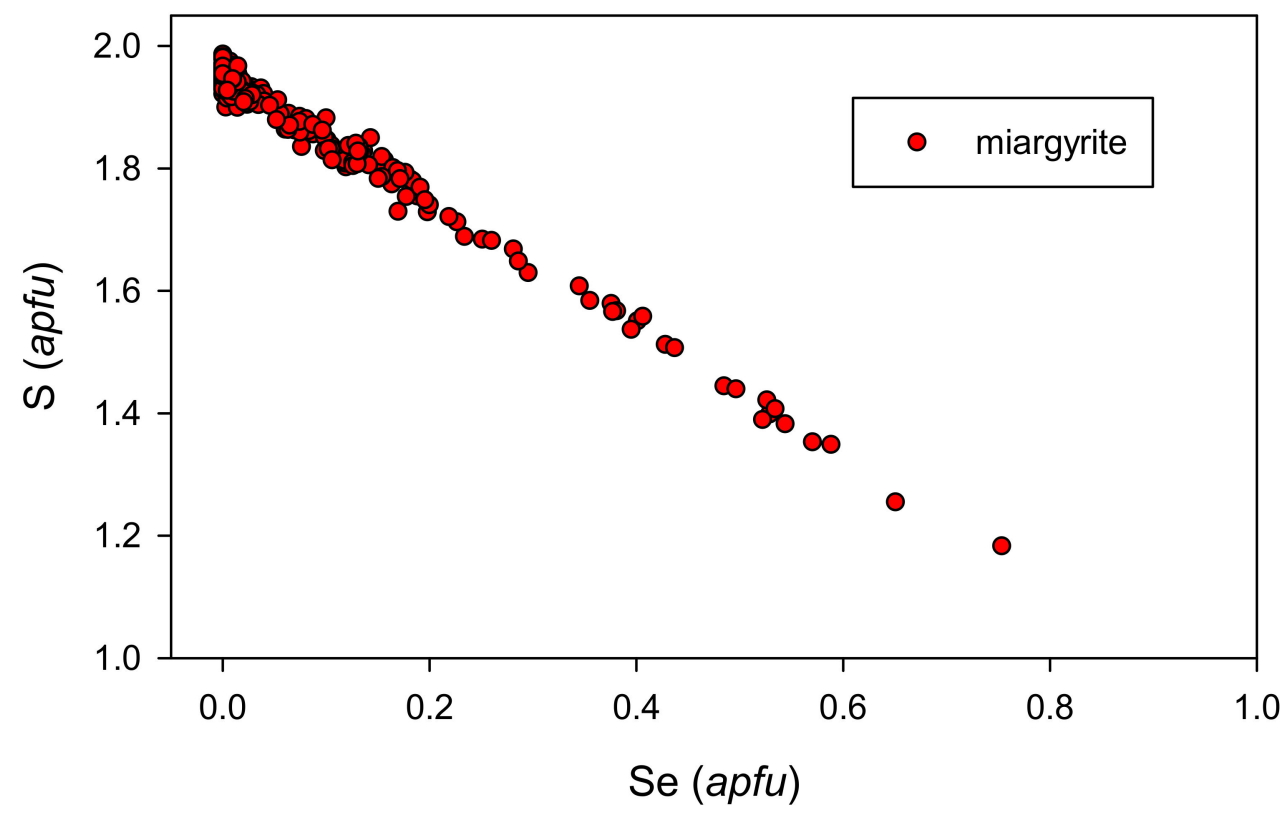

Figure 8. Graph of Se vs. S (apfu) for miargyrite from the Kremnica deposit. 


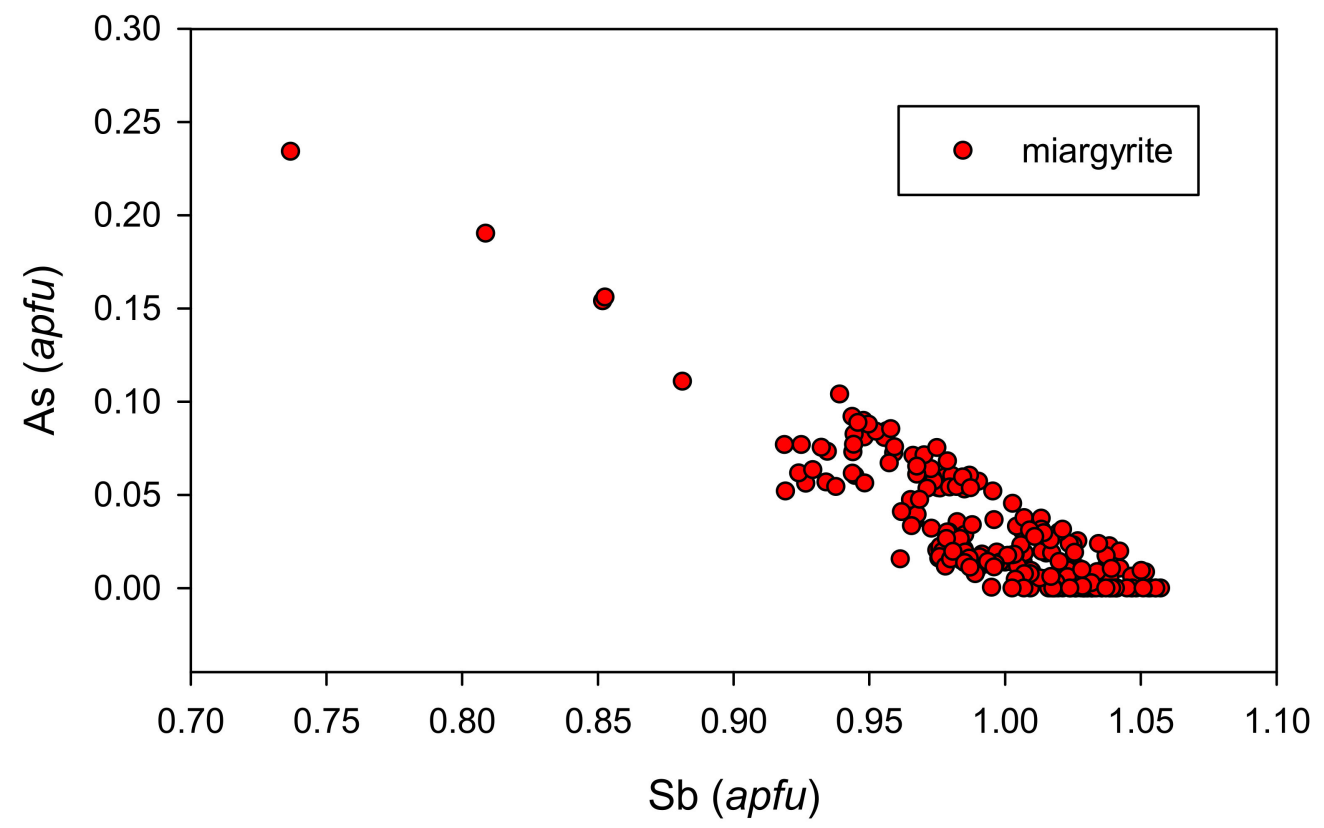

Figure 9. Graph of Sb vs. As (apfu) for miargyrite from the Kremnica deposit.
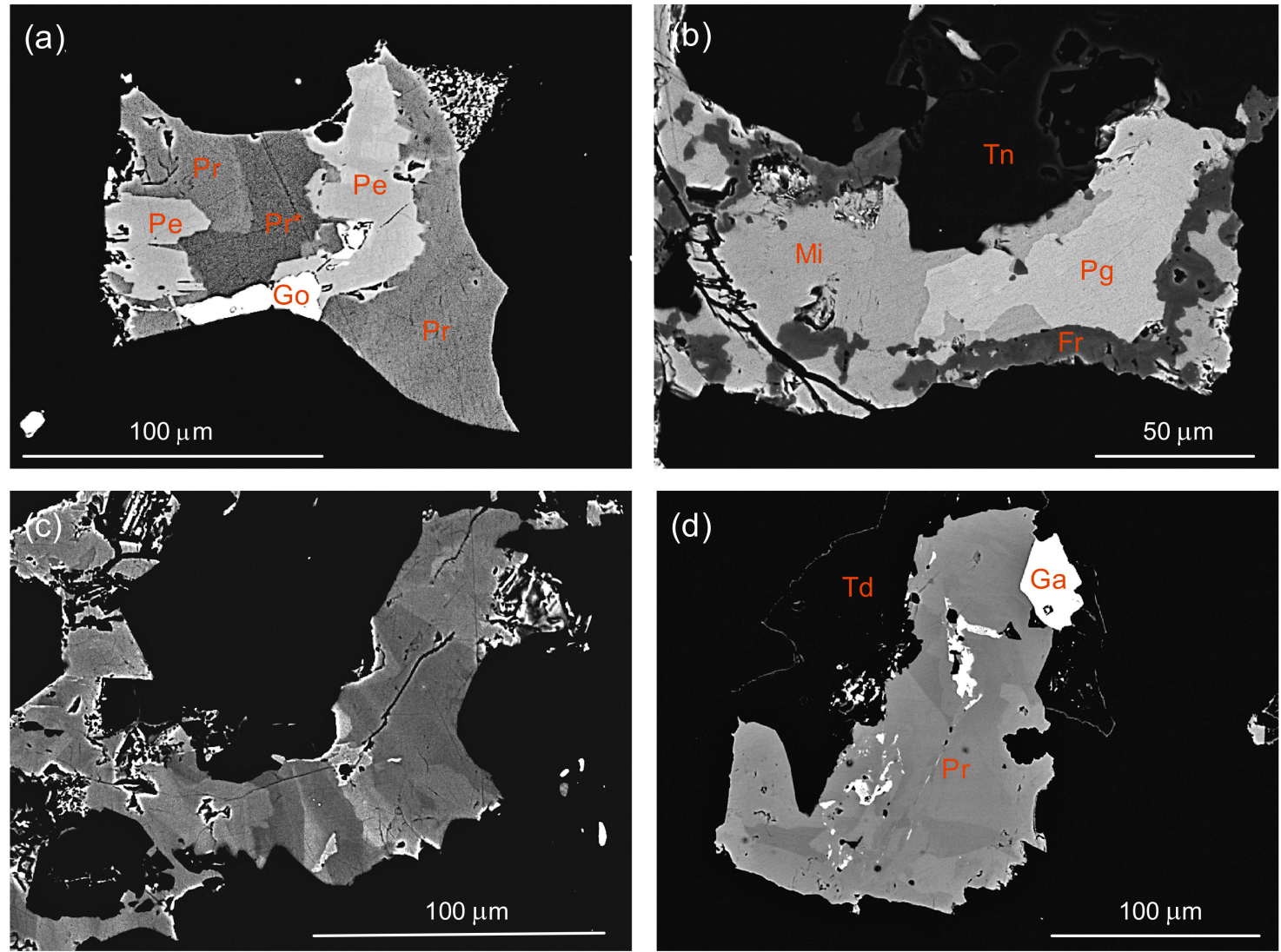

Figure 10. (a) Se-rich proustite $(\mathrm{Pr})$ and Se-free proustite $\left(\mathrm{Pr}^{*}\right)$ intergrown with pearceite $(\mathrm{Pe})$ and gold (Go); (b) pyrargyrite (Pg) associated with miargyrite (Mi), freibergite (Fr), and Ag-rich tennantite (Tn); (c) aggregates formed by members of pyrargyrite-proustite solid solution; (d) proustite aggregates with variable $\mathrm{Sb}$ and Se contents in association with galena and Ag-rich tetrahedrite; all back-scattered electron (BSE) images. 
The chemical composition of the studied samples (Figure 11) is covering the complete solid solution range between pyragyrite and proustite. The presence of the complete solid solution at the studied locality indicates the origin of these phases at temperatures above $200-300{ }^{\circ} \mathrm{C}[45,46]$; only limited miscibility was described for the lower temperatures by Ondruš et al. [47]. The determined Se contents do not correlate directly with As/Sb ratio, but range of $\mathrm{SeS}_{-1}$ substitution is larger in pyrargyrite (up to $0.76 \mathrm{apfu}$ ) than in the case of proustite with contents up to $0.52 \mathrm{apfu}$ Se (Figure 12). Besides main elements, traces of $\mathrm{Fe}, \mathrm{Pb}, \mathrm{Hg}, \mathrm{Cu}$, and $\mathrm{Cl}$ were also observed. The chemical analyses of members of the pyrargyrite-proustite series and corresponding empirical formulae are given in Table S6.

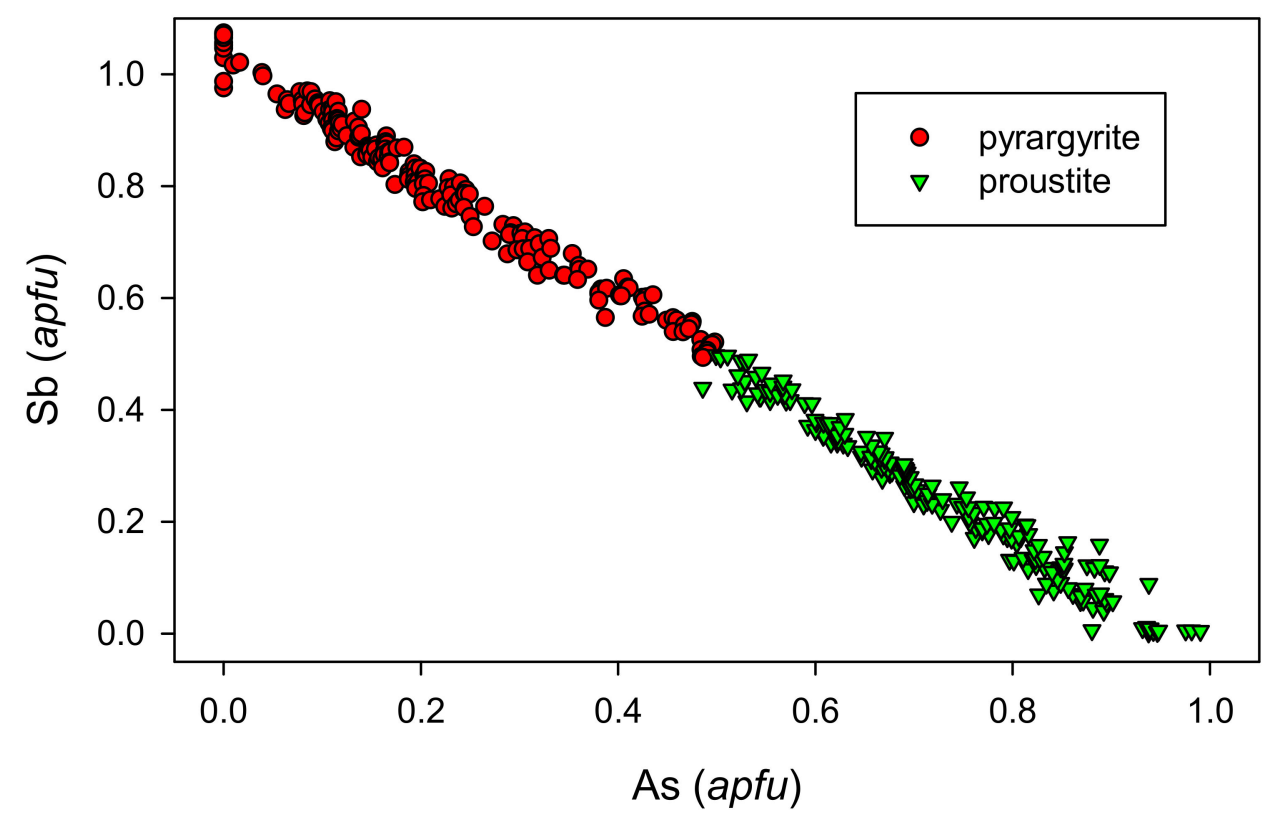

Figure 11. Graph of Sb vs. As (apfu) for minerals of the pyrargyrite-proustite solid solution series from the Kremnica deposit.

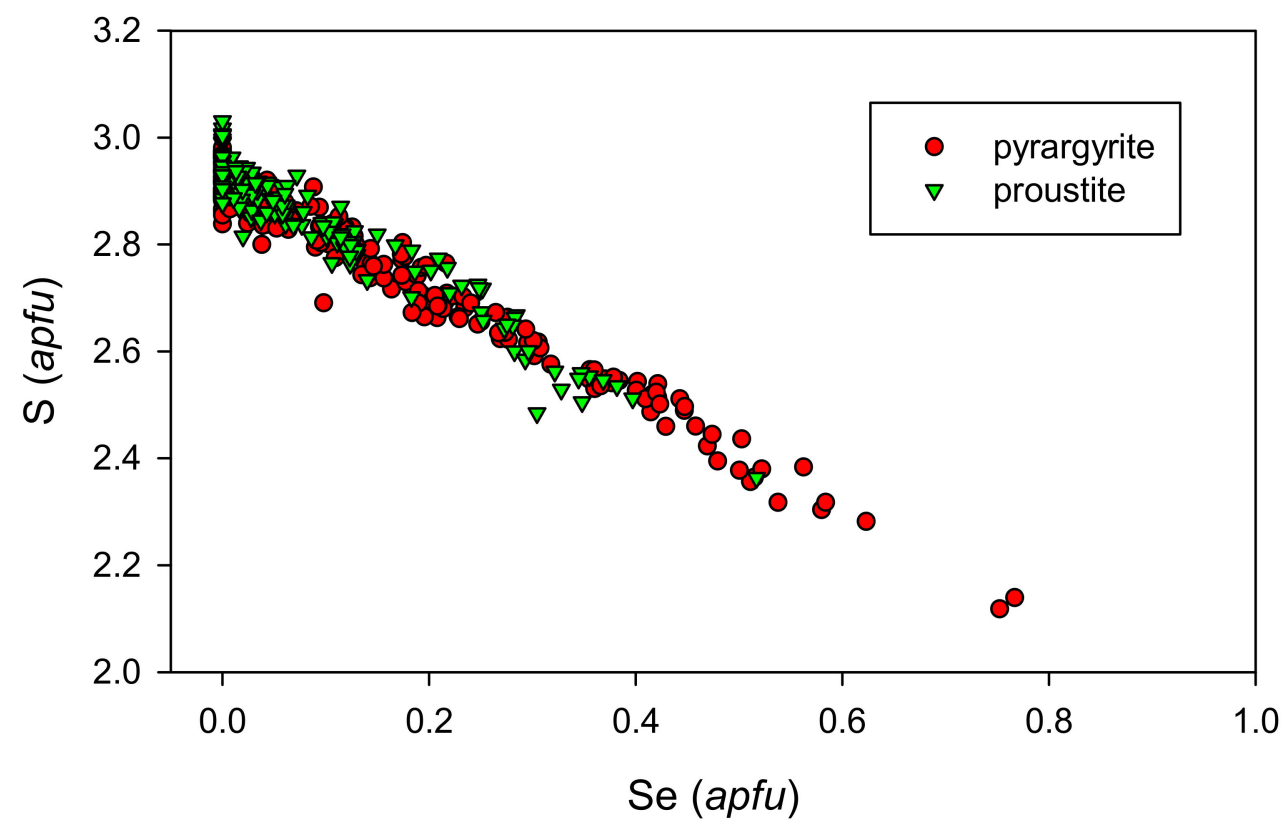

Figure 12. Graph of Se vs. S (apfu) for minerals of the pyrargyrite-proustite solid solution series from the Kremnica deposit. 


\subsection{Ag-Cu Sulphosalts}

Minerals of the tetrahedrite group are common. They form subhedral to anhedral grains and aggregates up to $250 \mu \mathrm{m}$ in size, which often show relatively strong irregular chemical zoning in BSE images (Figure 13). They are always closely associated together with miargyrite, pyrargyrite-proustite, galena-clausthalite, minerals of the polybasite group, diaphorite, and to a lesser extent also with acanthite, naumannite, and gold-silver alloy.
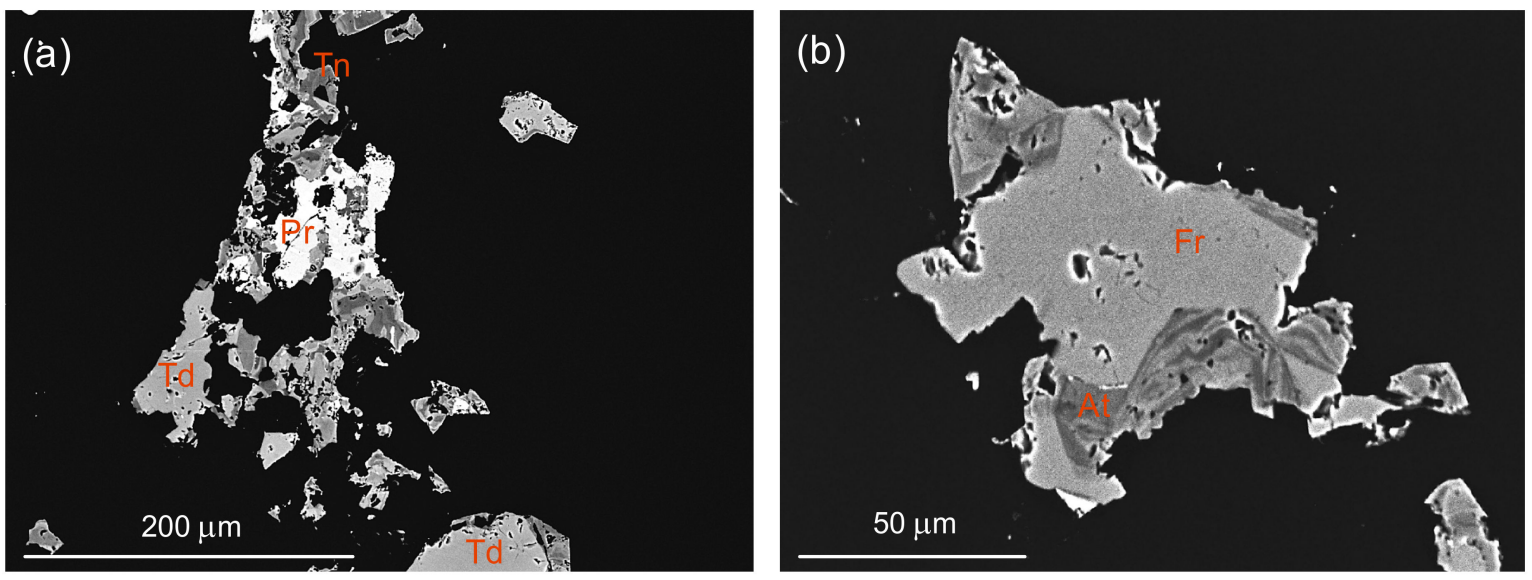

Figure 13. (a) Aggregates of members of Ag-rich tetrahedrite (Td)-tennantite (Tn) solid solution in association with proustite (Pr); (b) zonal aggregate of freibergite (Fr) and argentotennantite (At); both back-scattered electron (BSE) images.

The tetrahedrite group is the most complex isotypic series among the sulphosalts in nature. This is caused by the multiplicity of iso- and heterovalent substitutions [48]. A simplified general formula for minerals of the tetrahedrite group can be expressed according to Moëlo et al. [48] as ${ }^{[\mathrm{III}]} A_{6}{ }^{[\mathrm{IV}]}(B, C)_{6}{ }^{[\mathrm{III}]} \mathrm{X}_{4}{ }^{[\mathrm{IV}]} Y_{12}{ }^{[\mathrm{VI}]} Z_{1}$, where $A$ is $\mathrm{Cu}$ or $\mathrm{Ag}$ in triangular coordination; $B$ is $\mathrm{Cu}^{1+}$ or $\mathrm{Ag}$ in tetrahedral coordination, $C$ is generally a divalent metal (typically Fe or $\mathrm{Zn}$, but also $\mathrm{Hg}, \mathrm{Mn}, \mathrm{Cd}$, $\mathrm{Cu}^{2+}$, etc.) in the same coordination as $B ; X$ is $\mathrm{Sb}, \mathrm{As}, \mathrm{Bi}$ or Te in trigonal pyramidal coordination; $Y$ is $S$ or Se in tetrahedral coordination, and $Z$ is $S$ or Se in special octahedral coordination. Structural studies confirmed the presence of vacancies or interstitial atoms (e.g., $\mathrm{Cu}$ ), or heterovalent substitutions due to the incorporation of $\mathrm{Fe}^{3+}$ or $\mathrm{Te}^{4+}$ [48]. The status of Ag-rich members of tetrahedrite group (freibergite, argentotennantite) and especially their boundaries with tetrahedrite and tennantite is still discussed [48]. Part of authors proposed for freibergite minimum content of 4 apfu Ag [48,49] and for argentotennantite $\mathrm{Ag}>\mathrm{Cu}$ (about 5 apfu $\mathrm{Ag}$ ) [50]. On the base of the results of crystal structure studies $[49,51]$ and analyses of natural samples [52,53], Ag preferably occupies the triangular $A$ position with a total content $6 a p f u$, and according to the present rules of mineralogical nomenclature [54], the boundary would be three apfu Ag [53].

Four members from the tetrahedrite group were encountered in samples from Kremnica under this study: tetrahedrite, freibergite, tennantite, and argentotennantite. The tetrahedrite-group minerals form zonal aggregates with a high extent of substitution are in $A$ (Figure 14), $C$ (Figure 15), and $X$ sites (Figure 16). The contents of Se are low in tetrahedrite reaching up to $0.36 \mathrm{apfu}$, in freibergite up to 0.28 apfu, respectively; As dominant members are virtually Se-free. The $A$ position of tetrahedrite from the Kremnica deposit is dominantly occupied by $\mathrm{Cu}$; however, with regular $\mathrm{Ag}$ contents in the range 1.06-2.99 apfu (Table S7). According to occupancy of the $C$ site, there are present both Fe- and Zn-dominant members (Figure 15); minor contents of $\mathrm{Hg}$ (up to $0.18 \mathrm{apfu}$ ) were also determined in Fe-rich tetrahedrite. Antimony is the dominant element in the $X$ position and it is partly replaced by As in the range of 0.18-1.99 apfu (Figure 16). The $A$ site in freibergite is dominantly occupied by Ag with contents of 3.02-5.64 apfu (Table S8). In the $C$ position besides Fe-dominant freibergite (some with $\mathrm{Hg}$ contents up to $0.22 \mathrm{apfu}$ ), there is also an unusual $\mathrm{Zn}$-dominant one observed with $\mathrm{Zn}$ 
in the range of 1.00-1.87 apfu (Figure 15). Antimony in the X position is substituted by As reaching up to 2.01 apfu (Figure 16). In the chemical composition of tennantite (Table S9), the predominant $\mathrm{Cu}$ in the $A$ position is accompanied by Ag (0.67-3.00 apfu), in the $C$ position Fe with 1.41-2.16 apfu always prevails (Figure 15). In the $X$ position, the As is replaced by $\mathrm{Sb}$ in the range 0.26-1.99 apfu (Figure 16). According to obtained WDS analyses (Table S10), the $A$-site in argentotennantite is occupied, besides minor $\mathrm{Cu}$, by $\mathrm{Ag}$ in the range 3.03-4.68 apfu (Figure 14). In the $C$ position, Fe in the range of 1.33-1.99 apfu prevails over $\mathrm{Zn}$ (up to $0.77 \mathrm{apfu}$ ). As a dominating element in the $X$ position, it is replaced by $\mathrm{Sb}$ in the range of 0.73-1.95 apfu (Figure 16).

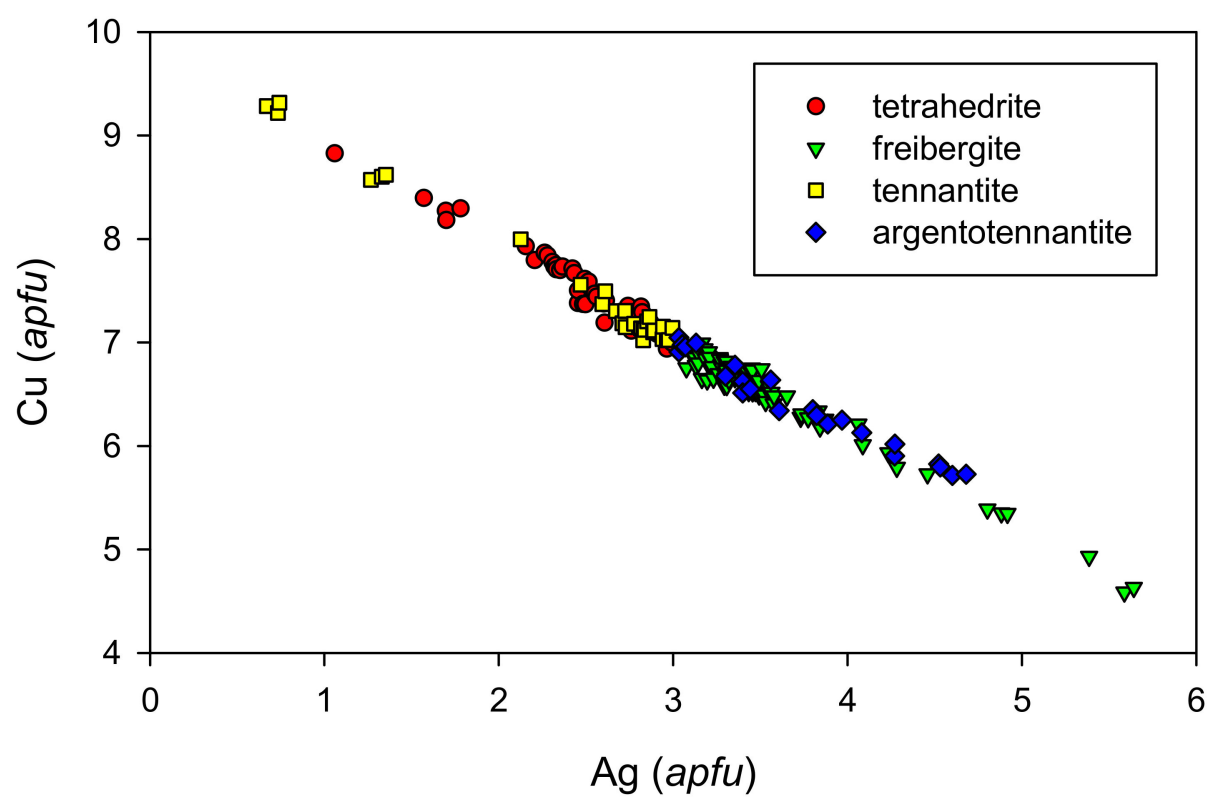

Figure 14. Graph of Ag vs. $\mathrm{Cu}(a p f u)$ for members of the tetrahedrite group from the Kremnica deposit.

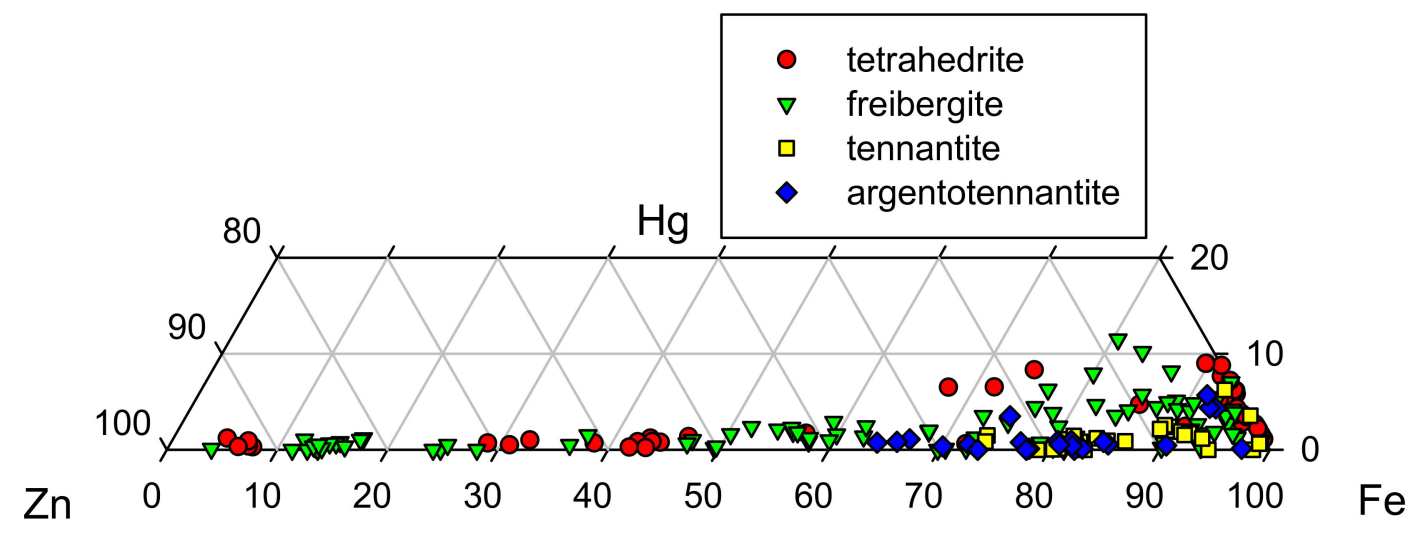

Figure 15. Part of the ternary Fe-Hg-Zn (apfu) plot for members of the tetrahedrite group from the Kremnica deposit. 


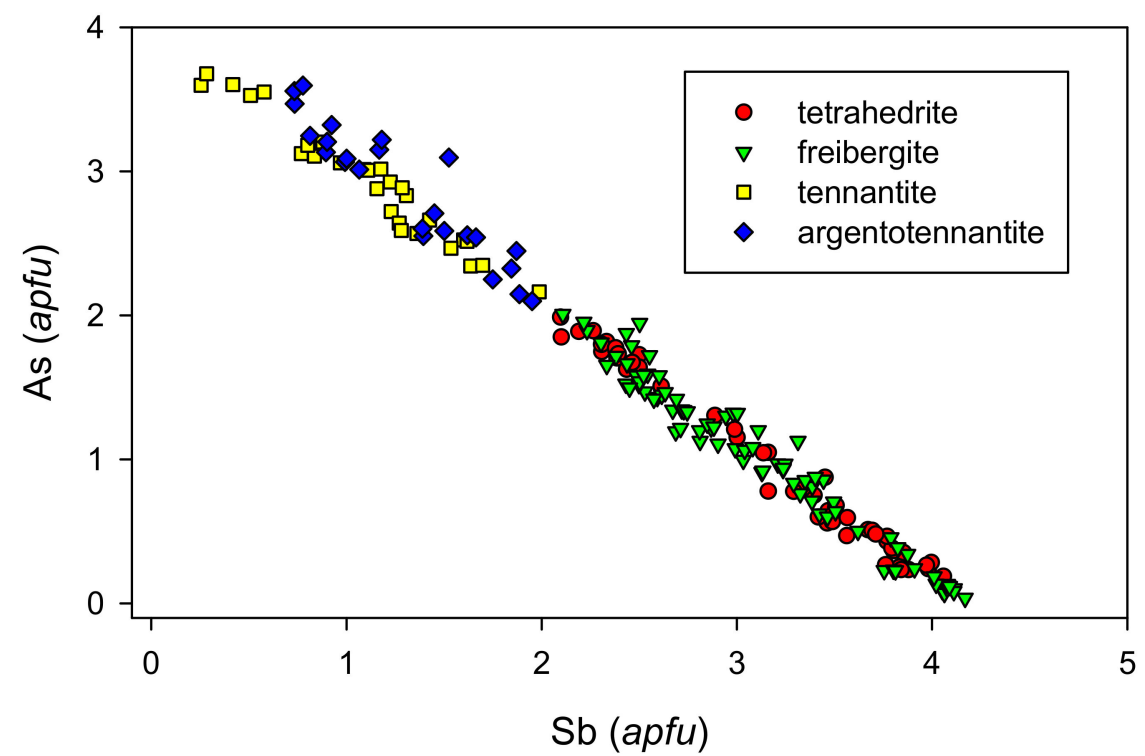

Figure 16. Graph of Sb vs. As (apfu) for members of the tetrahedrite group from the Kremnica deposit.
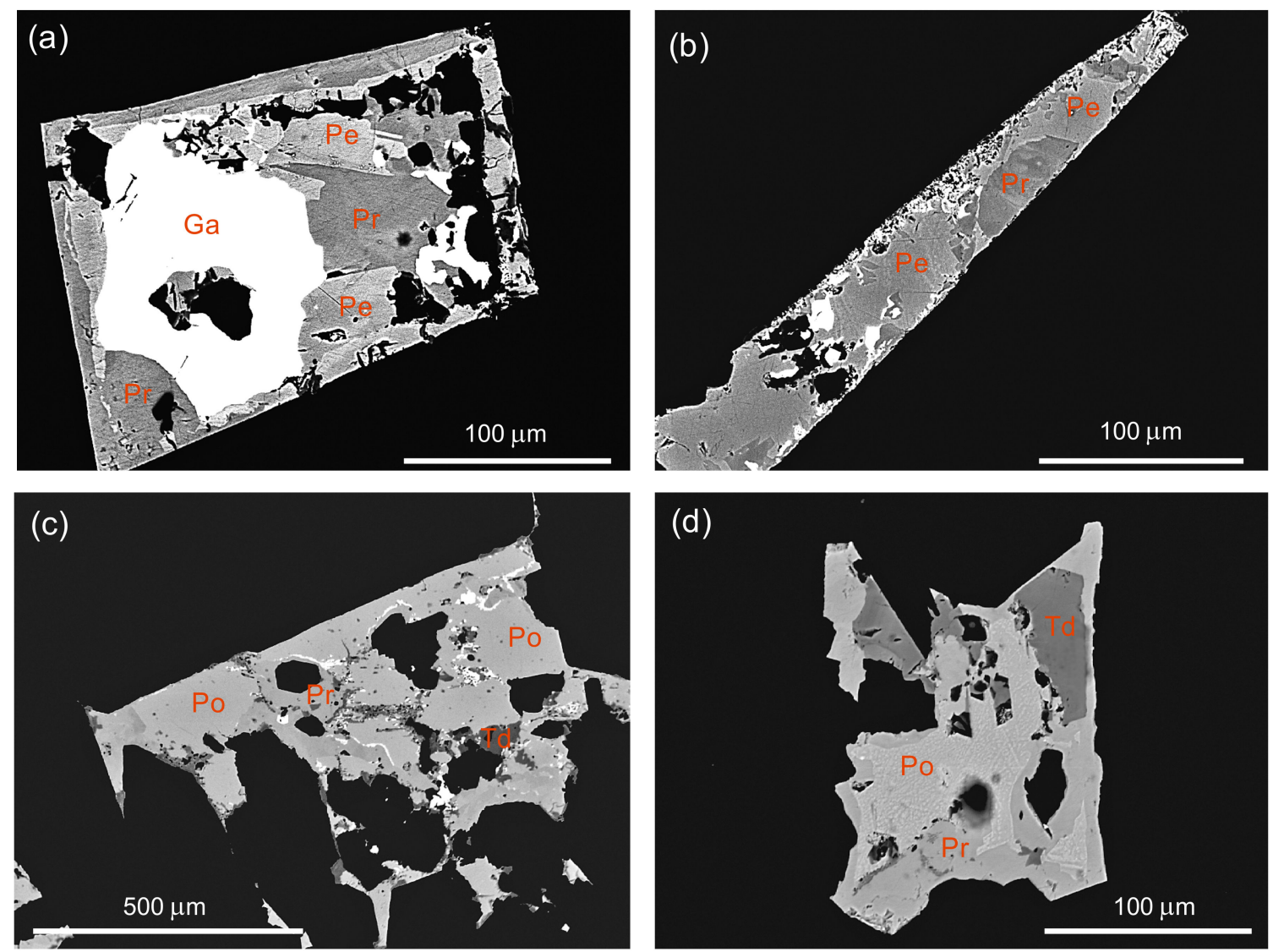

Figure 17. (a) Se-rich pearceite (Pe) associated with galena (Ga) and proustite (Pr); (b) pearceite (Pe) overgrown with proustite $(\mathrm{Pr})$; (c) polybasite $(\mathrm{Po})$ associated with proustite (Pr) and Ag-rich tetrahedrite (Td); (d) polybasite (Po) in association with proustite (Pr) and Ag-rich tetrahedrite (Td); all back-scattered electron (BSE) images.

Minerals of the polybasite group, $\left[\mathrm{Ag}_{9} \mathrm{CuS}_{4}\right]\left[(\mathrm{Ag}, \mathrm{Cu})_{6}(\mathrm{As}, \mathrm{Sb})_{2} \mathrm{~S}_{7}\right]$, are fairly common as subhedral and anhedral grains up to $300 \mu \mathrm{m}$ in size (Figure 17), which are mostly associated with 
pyrargyrite-proustite, minerals of the tetrahedrite group, and galena-clausthalite. They often show weak irregular chemical zoning in BSE images (Figure 17a,b).

The nomenclature of the polybasite group has recently been clarified through the resolution of the crystal structures of various polytypes of this group by Bindi et al. [55], and a general formula $\left[\mathrm{Ag}_{9} \mathrm{CuS}_{4}\right]\left[(\mathrm{Ag}, \mathrm{Cu})_{6}(\mathrm{As}, \mathrm{Sb})_{2} \mathrm{~S}_{7}\right]$ was proposed. As the first selenium-dominant member, selenopolybasite with a formula of $\left[\mathrm{Ag} 9{ }_{9} \mathrm{Cu}(\mathrm{S}, \mathrm{Se})_{2} \mathrm{Se}_{2}\right]\left[(\mathrm{Ag}, \mathrm{Cu})_{6}(\mathrm{As}, \mathrm{Sb})_{2}(\mathrm{~S}, \mathrm{Se})_{7}\right]$ was described by Bindi et al. [56].

Four members of the polybasite group were determined in the studied material from the Kremnica deposit: polybasite, selenopolybasite, pearceite, and a new unnamed Se-analogue of pearceite referred to as "selenopearceite" in the following text. The members of the polybasite group form zonal aggregates with high extent of substitutions As-Sb, Ag-Cu (Figure 18), and Se-S (Figure 19). Polybasite is characterized by contents of $\mathrm{Cu}$ in the range 0.83-2.48 apfu and As 0.11-1.13 apfu, respectively (Table S11). In the anion sites, S is partly substituted by Se (up to 1.88 apfu). Selenopolybasite has $\mathrm{Cu}$ contents around 1 apfu (0.69-1.40) and the range of $\mathrm{AsSb}_{-1}$ substitution is 0.30-0.98 apfu (Table S12). The minimum content of $2 a p f u$ Se in anion positions was determined as a boundary between polybasite and selenopolybasite; selenopolybasite from type locality De Lamar mine, Idaho, USA, contains up to 2.55 apfu Se [56], but significant is that selenium fully occupies one specific site with general content of 2 apfu [57]. Polybasites with about 1 apfu Se were also found, but in the case of this reduced content, selenium is disordered in the anion positions of the A layer of the crystal structure [58]. In the selenopolybasite from the Kremnica deposit, the Se contents in the range 2.01-3.56 apfu were determined (Figure 19). In chemical composition of As-dominant member, pearceite, As is partly replaced by $\mathrm{Sb}$ up to 1.09 apfu (Figure 18) and $\mathrm{Cu}$ content varies in the range 0.63-2.27 apfu (Table S13). The observed Se contents reach up to 1.91 apfu. For the last member of this group, the new unnamed "selenopearceite", the contents of $\mathrm{Cu}$ around 1 apfu (0.64-1.55) and Sb up to 1.04 apfu were determined (Table S14). The observed range of SeS-1 substitution is 2.08-3.54 apfu (Figure 19); similar high contents of selenium in pearceite (as an As-dominant member) have not been described yet.

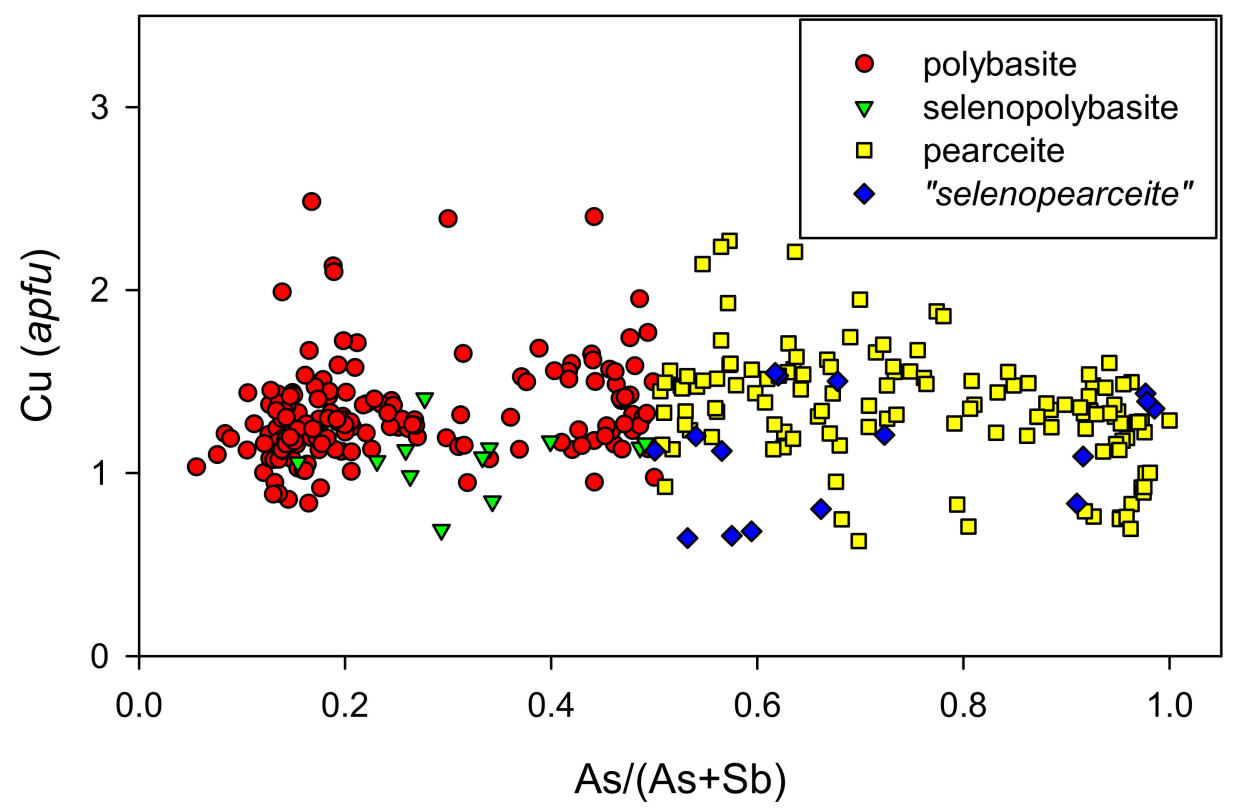

Figure 18. Graph of $\mathrm{As} /(\mathrm{As}+\mathrm{Sb})$ vs. $\mathrm{Cu}(a p f u)$ for members of the polybasite group from the Kremnica deposit. 


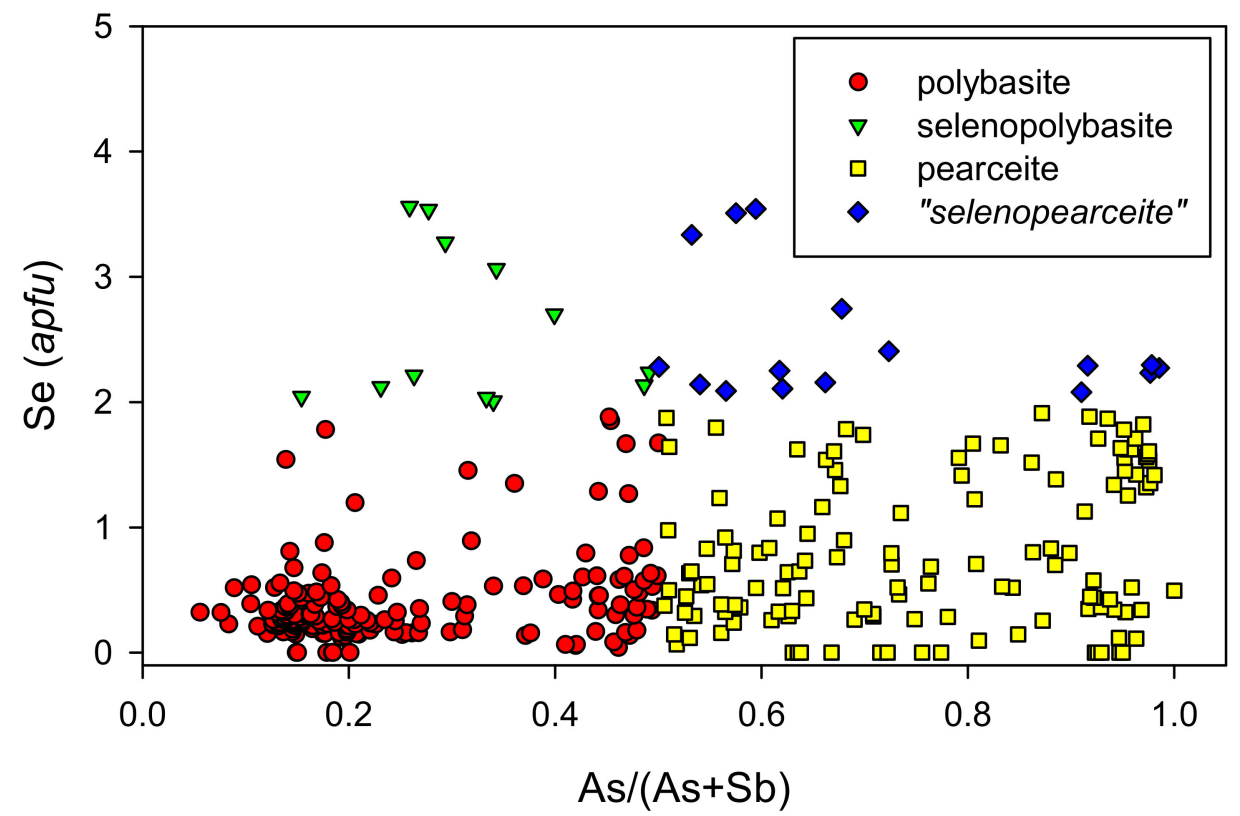

Figure 19. Graph of $\mathrm{As} /(\mathrm{As}+\mathrm{Sb})$ vs. Se $(a p f u)$ for members of the polybasite group from the Kremnica deposit.

\subsection{Ag-Pb Sulphosalts}

Diaphorite, $\mathrm{Ag}_{3} \mathrm{~Pb}_{2} \mathrm{Sb}_{3} \mathrm{~S}_{8}$, is a relatively common mineral in the studied mineral association. It occurs as anhedral grains and aggregates up to $150 \mu \mathrm{m}$ in size (Figure 20), which replace galena and are predominantly associated with miargyrite, pyrargyrite-proustite, and minerals of the tetrahedrite group.
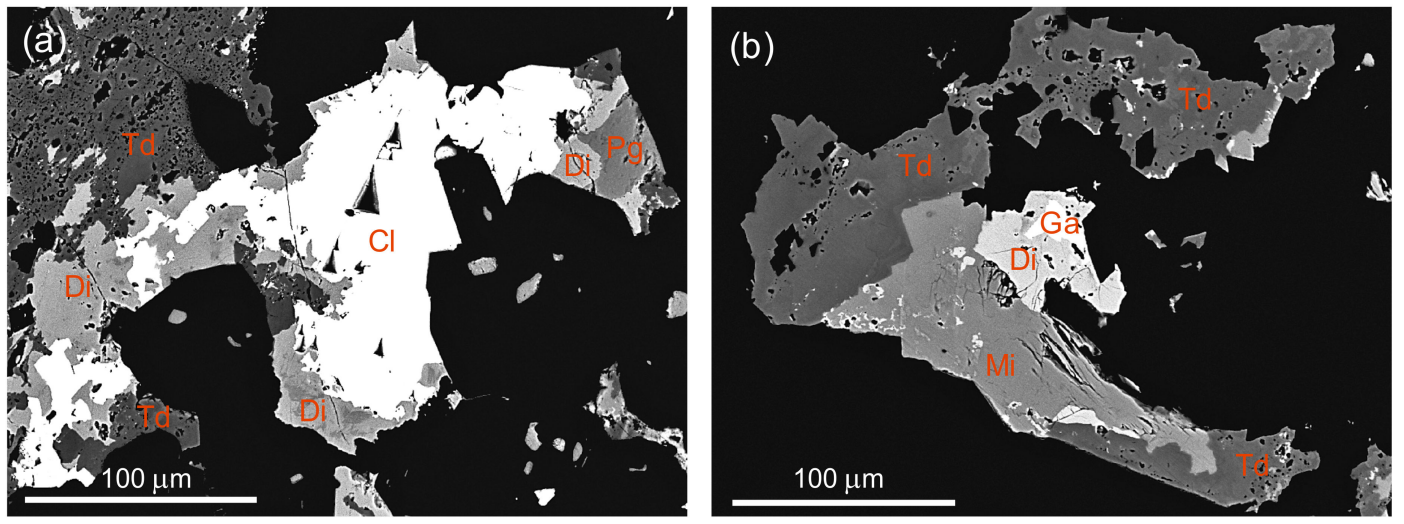

Figure 20. (a) Diaphorite (Di) in association with clausthalite $(\mathrm{Cl})$, pyrargyrite $(\mathrm{Pg})$, and Ag-rich tetrahedrite $(\mathrm{Td})$; $(\mathbf{b})$ diaphorite $(\mathrm{Di})$ associated with galena $(\mathrm{Ga})$, miargyrite $(\mathrm{Mi})$, and Ag-rich tetrahedrite (Td); both back-scattered electron (BSE) images.

The chemical composition of diaphorite from the Kremnica deposit (Table S15) slightly differs from the ideal formula, $\mathrm{Ag}_{3} \mathrm{~Pb}_{2} \mathrm{Sb}_{3} \mathrm{~S}_{8}$, especially in the $\mathrm{Ag} / \mathrm{Pb}$ ratio, which ranges from 1.63 to 1.98 (Figure 21). The similar variations were described by Mozgova et al. [59] on the basis of microanalytical and crystallographic data from various occurrences of diaphorite. Mozgova et al. (1989) [59] speculated about the existence of a continuous solid solution series between diaphorite and a phase with the formula $\mathrm{Ag}_{2} \mathrm{PbSb}_{2} \mathrm{~S}_{5}$ (old non-valid name "brongniardite") and concluded that this phase with $\mathrm{Ag} / \mathrm{Pb}$ ratios between 1.75 and 2.00 may be called as Ag-rich diaphorite. This hypothesis is supported by results of a study of diaphorite from Herja, Romania (Ag/Pb = 1.53-1.69) [60], Apuan Alps, Italy ( $\mathrm{Ag} / \mathrm{Pb}=1.67)$ [61], and Poličany, Czech Republic 
$(\mathrm{Ag} / \mathrm{Pb}=1.47-1.80)$ [42]. Diaphorite samples with a composition close to the ideal stoichiometry $(\mathrm{Ag} / \mathrm{Pb}=1.44-1.54)$ were found at other localities, such as Kutná Hora, Czech Republic [62,63] and Příbram, Czech Republic [64]. The determined minor contents of As (up to 0.34 apfu) in diaphorite from Kremnica negatively correlates with $\mathrm{Sb}$, indicating the existence of the $\mathrm{AsSb}_{-1}$ substitution. The observed range of SSe-1 substitution in the anion part of the formula (up to $0.86 a p f u$ ) are significantly higher than those published for Se-bearing diaphorite from Kutná Hora, Czech Republic (up to 0.29 apfu Se) [42].

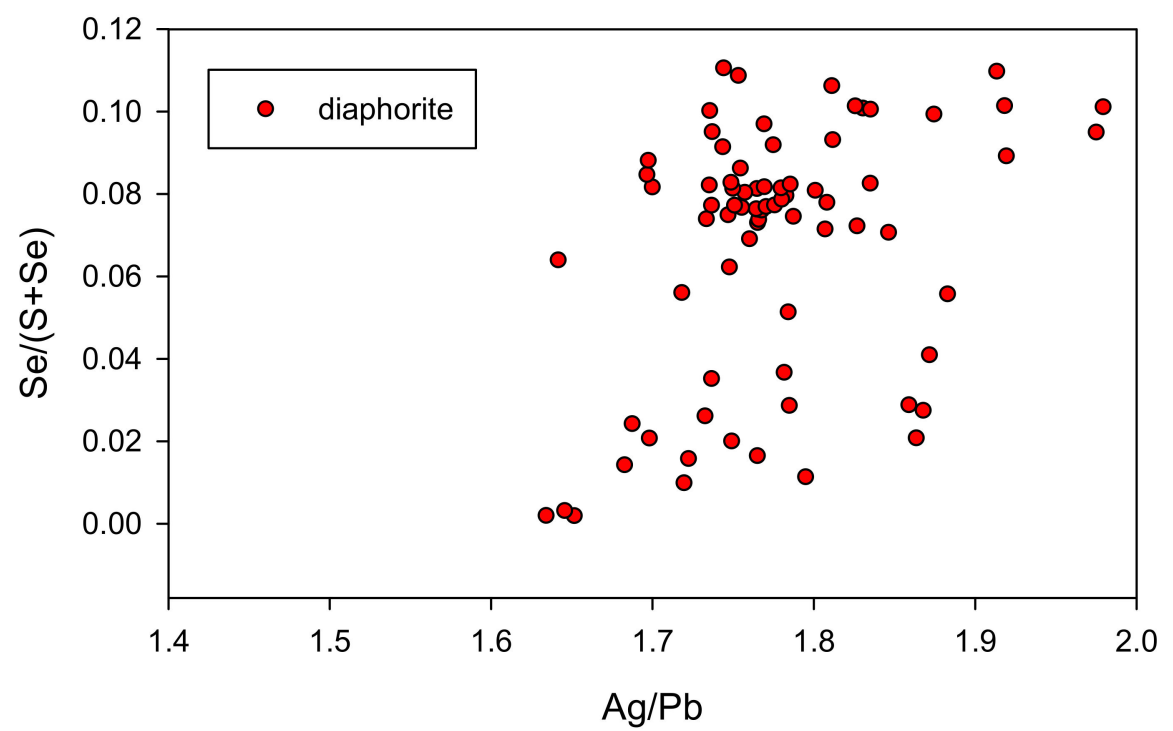

Figure 21. Graph of $\mathrm{Ag} / \mathrm{Pb}$ vs. Se/(S + Se) (apfu) for diaphorite from the Kremnica deposit.

Minerals of the andorite branch are relatively rare. They occur as subhedral and anhedral grains and aggregate up to $100 \mu \mathrm{m}$ in size, which show slight irregular to oscillatory chemical zoning in BSE images (Figure 22). The most common associated minerals are miargyrite, pyrargyrite-proustite, galena-clausthalite, and minerals of the tetrahedrite group. Minor amounts of freieslebenite, scainiite, plagionite, and robinsonite were also observed together with andorites.

The results of chemical analyses of andorite $\mathrm{VI}, \mathbf{P b}_{18} \mathbf{A g}_{15} \mathbf{S b}_{47} \mathbf{S}_{96}$ shows for the majority of analytical points its over-substituted character with \% of and substitution reaching up to 112 (Figure 23). This chemical composition corresponds to the so-called nakaséite defined by Ito and Muraoka [65] with $106 \%$ And, which was later confirmed by Moëlo et al. [66] to be an oversubstituted, Cu-rich (about $1 \mathrm{wt} \%$ ) variety of andorite VI; the contents of $\mathrm{Cu}$ in the studied material from Kremnica reaches up to $1.1 \mathrm{wt} \%$ (Table S16). The presence of very thin zones with different chemical compositions observed in BSE images (Figure 22b,c) suggests also a possibility of exsolution of structures of andorite VI and a mineral phase close to roshchinite $[67,68]$.

During the study of chemical composition of andorite $\mathbf{I V}, \mathbf{A g P b S b}_{3} \mathbf{S}_{\mathbf{6}}$, (Table S17, Figure 23) the $\mathrm{N}_{\text {chem }}$ values between 3.99-4.14 (mean 4.05) and \% and substitution 91-96 (mean 94) were found, which is in good agreement with published data [66]. 

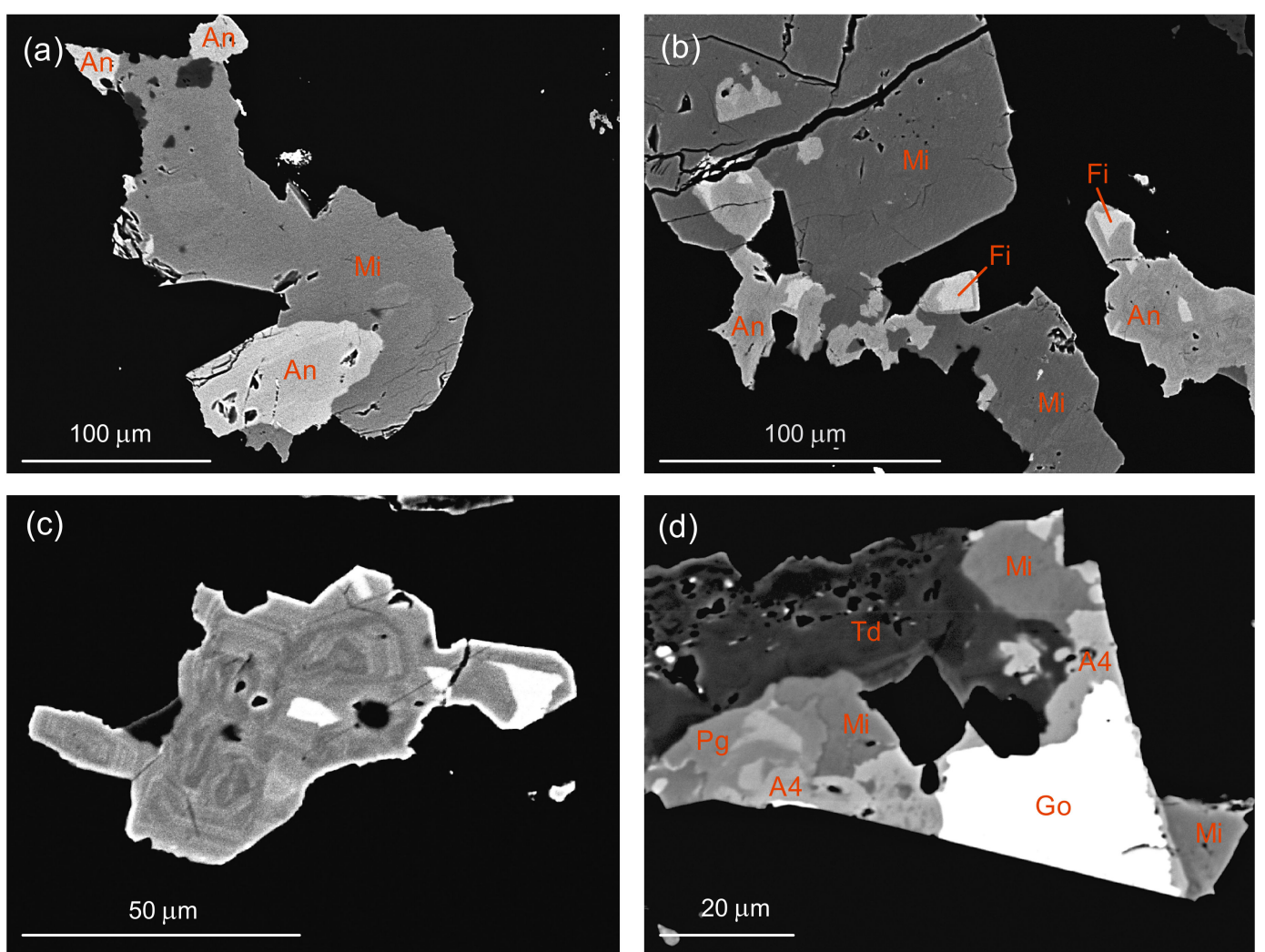

Figure 22. (a) Andorite VI (An) associated with miargyrite (Mi); (b) andorite VI (An) intergrown with Ag-excess fizélyite (Fi) and miargyrite (Mi); (c) zonal andorite VI aggregate with inclusions of Ag-excess fizélyite (white); (d) aggregates of andorite IV (A4) in association with gold (Go), miargyrite (Mi), pyrargyrite (Pg), and Ag-rich tetrahedrite (Td); all back-scattered electron (BSE) images.

A mineral phase with $\mathrm{N}_{\text {chem }}$ value in the range 4.39-4.72 and \% and substitution 67-70 (Figure 23, Table S18) corresponds very well with so-called Ag-excess fizélyite. It was described for the first time on the basis of chemical composition as "minéral F" from Les Farges in France by Moëlo et al. [66] and later from the Lill mine in Př́bram, Czech Republic, by Plášil et al. [69]. Structurally, it was defined by Yang et al. [70] in samples from Van Silver mine, Canada. It significantly differs from fizélyite by higher $\mathrm{Ag}$ contents; the excess silver is situated at the $\mathrm{Ag} 2$ site in the crystal structure [70], which remains unoccupied in "standard" fizélyite. Higher Ag contents results in a shift of calculated $\mathrm{N}_{\text {chem }}$ (the width of the blocks of octahedra separated by $\mathrm{Pb}$ atoms in trigonal prismatic coordination) to higher values than four. The mineral from the Van Silver mine shows calculated values of $\mathrm{N}_{\text {chem }}$ in the range of 4.31-4.59 with a mean of 4.42 [70], whereas those described recently from Poličany, Czech Republic, shows a wider range of $\mathrm{N}_{\text {chem }}$ values of 4.27-4.91 with mean of 4.54 [42].

The selenium contents in minerals of the andorite branch are relatively low (Figure 24). The higher range of $\mathrm{SeS}_{-1}$ substitution (up to $5.71 \mathrm{wt} \% \mathrm{Se}$ ) was determined for some aggregates of andorite IV and VI only.

Freieslebenite, $\mathrm{AgPbSbS}_{3}$, is very rare. It forms irregular anhedral grains and inclusions up to $20 \mu \mathrm{m}$ in size enclosed in andorite, which are associated with Se-rich miargyrite. Its chemical composition is close to the ideal formula (Table S19); only minor contents of As (up to 0.08 apfu) were determined. Selenium contents are also low (up to $0.01 \mathrm{apfu}$ ). 


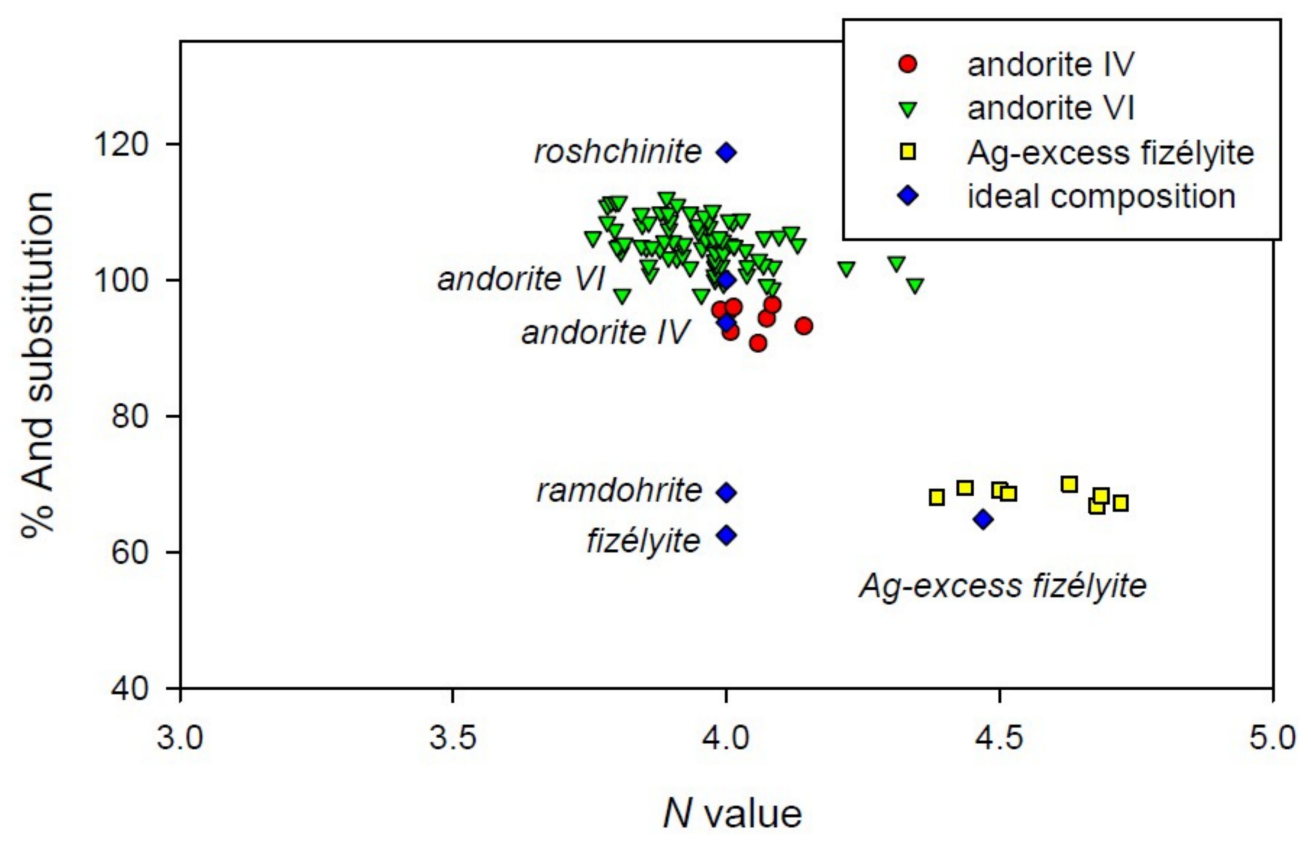

Figure 23. Graph of $\mathrm{N}$ value vs. \% of And substitution for members of the andorite branch from the Kremnica deposit.

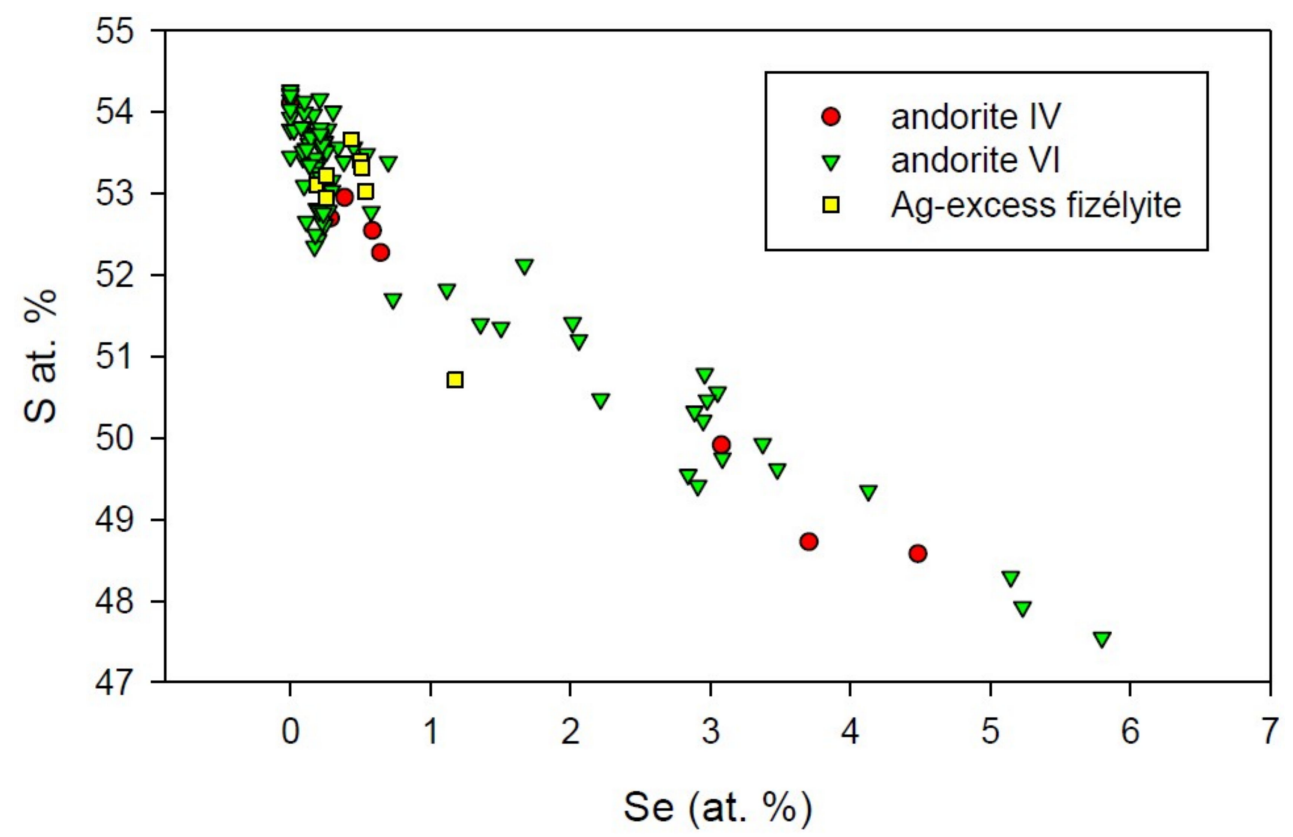

Figure 24. Graph of Se vs. S contents (at. \%) for members of the andorite branch from the Kremnica deposit.

\section{6. $\mathrm{Pb}-\mathrm{Sb}$ sulphosalts}

Scainiite, $\mathrm{Pb}_{14} \mathrm{Sb}_{30} \mathrm{~S}_{54} \mathrm{O}_{5}$, is very rare. It occurs as anhedral grains up to $10 \mu \mathrm{m}$ in size associated with robinsonite, plagionite, andorite, Se-poor galena, and miargyrite (Figure 25). Its chemical composition (Table S20) is close to published data for scainiite from the type occurrence in Buca della Vena mine, Italy [71]; moreover, minor contents of $\mathrm{Ag}, \mathrm{Fe}, \mathrm{Cu}$, and $\mathrm{Hg}$ were identified. In anionic site, only irregular contents of Se up to 3.68 apfu (3.49 wt \%) were observed. 

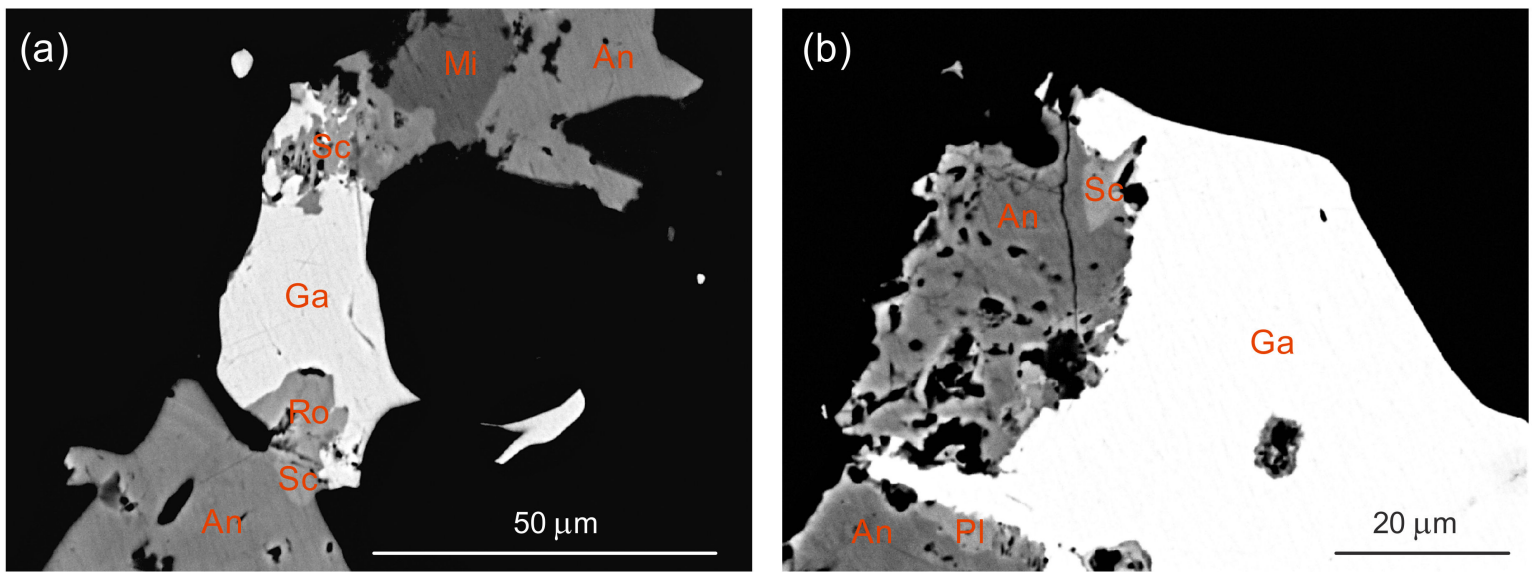

Figure 25. (a) Robinsonite (Ro) and scainiite (Sc) in association with galena (Ga), miagyrite (Mi), and andorite VI (An); (b) plagionite (Pl) and scainiite (Sc) associated with galena (Ga), and andorite VI (An); both back-scattered electron (BSE) images.

Plagionite, $\mathbf{P b}_{5} \mathbf{S b}_{8} \mathbf{S}_{17}$, is also very rare. It forms single elongated grains $15 \mu \mathrm{m}$ in size, which are associated with andorite, Se-poor galena, and scainiite (Figure 25b). Its chemical composition (Table S21) corresponds to the ideal formula $\mathrm{Pb}_{5} \mathrm{Sb}_{8} \mathrm{~S}_{17}$ [48]. The determined minor contents of $\mathrm{Ag}, \mathrm{Fe}, \mathrm{Hg}$, and $\mathrm{Cu}$ may be caused by surrounding phases. Apart from sulphur, the anionic site contains minor amounts of selenium reaching up to 1.24 apfu (3.81 wt \%).

Robinsonite, $\mathbf{P b}_{4} \mathrm{Sb}_{6} \mathrm{~S}_{13}$, was found only in one polished section, which also contained scainiite and plagionite. It forms single irregular grains $15 \mu \mathrm{m}$ in size (Figure 25a), which are accompanied with scainiite, Se-poor galena, andorite, and minor miargyrite. Its chemical analyses (Table S22) are close to the ideal composition $\mathrm{Pb}_{4} \mathrm{Sb}_{6} \mathrm{~S}_{13}$ [48], the observed minor amounts of $\mathrm{Ag}$, $\mathrm{Fe}$, and $\mathrm{Cu}$ may be caused by surrounding mineral phases. In anionic site, contents of Se up to 0.71 apfu $(2.80 \mathrm{wt} \%)$ were determined.

\section{Discussion}

\subsection{Paragenetic Evolution of Ore Mineralization}

The ore minerals form usually small ( $\mathrm{mm}$ to tenths of $\mathrm{mm}$ big) mutually isolated aggregates enclosed in quartz or fillings of comparatively small cavities in gangue minerals (both quartz and dolomite). No crosscutting phenomena have been observed among individual ore minerals in the studied polished sections indicating virtual absence of tectonic movements during crystallization of the vein filling. Although the studied mineralization is very rich in number of mineral species, much more limited amounts of ore phases (i.e., up to six) are present in individual ore aggregates. Moreover, tiny grains of many phases occur very sporadically. All these features make difficult the construction of a unified general paragenetic sequence involving all above described ore species.

The paragenetic evolution of ore mineralization can be divided into three portions based on their relative ages: early, middle, and late. This notation is mainly due to reader's comfort, it does not represent individual substages separated by tectonic events.

The early portion of the studied ore paragenesis includes base-metal sulphides, $\mathrm{Au}-\mathrm{Ag}$ alloys, and minerals of the galena-clausthalite series. The base-metal sulphides (sphalerite, pyrite, chalcopyrite) represent the oldest part of ore mineralization. These minerals form aggregates, which are typically not spatially associated with younger $\mathrm{Au}-\mathrm{Ag}$ mineralization. In addition, overall absence of selenium in base-metal sulphides also suggests their pertinence to a mineralizing event not related to the Se-bearing $\mathrm{Au}-\mathrm{Ag}$ mineralization. The early phases of the younger $\mathrm{Au}-\mathrm{Ag}$ mineralization are represented by $\mathrm{Au}-\mathrm{Ag}$ alloys and minerals of the galena-clausthalite series. These phases typically form relatively small individual isolated grains, surrounded (or replaced) by mineral phases 
belonging to the middle and late associations. Both phases are almost never in mutual contact; only one observation indicated that native gold is older than galena. We have not observed some systematic differences in mineral parageneses associated with compositionally different members of the galena-clausthalite series as well as gold-silver series. The plausible component of the early portion of the studied mineral assemblage is probably also uytenbogaardtite, which was observed only in the form of an overgrowth on a gold particle, enclosed in miargyrite.

The middle portion of the studied ore assemblage seems to be mineralogically very different in various samples and/or individual ore aggregates within a single sample. Common features characterizing this part of the studied paragenesis are: (i) spatial relationship to grains of minerals of the galena-clausthalite series; and (ii) a clear replacement relation of at least the early portion of newly formed mineral phases to the minerals of the galena-clausthalite series. Three principal mineral assemblages were observed in the middle paragenetic position:

2a: $\mathrm{Pb}-\mathrm{Sb}$ sulphosalts (robinsonite, scainiite, plagionite) followed by $\mathrm{Pb}-\mathrm{Ag}$ sulphosalts (Ag-excess fizélyite, andorites);

2b: diaphorite;

2c: minerals of the acanthite-naumannite compositional series.

In most cases, these mineralogically distinct assemblages seem to occur separately. In one case, small isolated inclusions of diaphorite occurred together with inclusions of andorite (both enclosed in miargyrite), but the mutual relationship of both phases is not clear. The reasons that led to the formation of such three paragenetically different assemblages remains unclear. The observed generally antipathetic relationships among these three parageneses can be the result of continuous temporal evolution of chemical composition of ore fluids (i.e., from a $\mathrm{Pb}-\mathrm{Sb}$-rich via $\mathrm{Pb}-\mathrm{Ag}$ - $\mathrm{Sb}$ to an $\mathrm{Ag}$-rich one) in combination with missing textural evidence for continuous evolution of mineral paragenesis. Alternatively, mixing of two ore fluids with contrasting chemical compositions (i.e., one $\mathrm{Pb}-\mathrm{Sb}$-rich and another Ag-rich) may be another possibility, which can explain the precipitation of virtually coeval very different mineral assemblages occurring at different places.

The youngest portion of the studied ore assemblage includes minerals of the pyrargyrite-proustite series, miargyrite, minerals of the polybasite group, and minerals of the tetrahedrite group. Therefore, parent fluids were rich in $\mathrm{Ag}, \mathrm{Cu}, \mathrm{Sb}$, and As. The following three paragenetic sequences were observed:

3a: Pyrargyrite $\rightarrow$ miargyrite $\rightarrow$ tetrahedrite group minerals;

3b: Polybasite/pearceite $\rightarrow$ proustite $\rightarrow$ tetrahedrite group minerals;

3c: Proustite/pyrargyrite $\rightarrow$ pearceite.

Paragenesis $3 a$ is generally Sb-rich, whereas assemblages $3 b$ and $3 c$ show much greater involvement of As. This can indicate participation of two fluids with contrasting compositions. An opposite temporal relationship between proustite and pearceite in assemblages $3 \mathrm{~b}$ and $3 \mathrm{c}$ can reflect the presence of multiple generations of these phases (but not indicated by systematic differences in chemical composition of these phases), or essentially coeval crystallization of both phases. The latter possibility can be supported by situation in one ore aggregate, where subordinate pearceite/polybasite forms graphic-like intergrowths with pyrargyrite/proustite host. In minerals of the polybasite group, pyrargyrite-proustite series as well as silver-rich tetrahedrites, there the $\mathrm{As} /(\mathrm{As}+\mathrm{Sb})$ ratio tends to increase during crystallization.

\subsection{Comparison with Similar Epithermal Mineralizations}

The ore association of the studied vein mineralization is characterized by the presence of abundant base-metal sulphides (galena and sphalerite besides pyrite), $\mathrm{Pb}-\mathrm{Sb}$ (-Ag) sulphosalts, native silver to Ag-rich gold (electrum), selenides and Se-enriched sulphides. By contrast, tellurides and Mo-minerals are missing. The mineralization is thus characterized by high $\mathrm{Ag} / \mathrm{Au}$ and Se/Te ratios. Gangue contains abundant dolomite in addition to quartz. Wall-rock alterations gave rise to abundant 
adularia and illite/smectite, whereas alunite is missing. These mineralogical and geochemical features suggest the pertinence of the studied vein to the low-sulphidation epithermal mineralizations [72].

In the area of the neighbouring Štiavnica Ore Districts, similar Au-Ag low-sulphidation vein mineralization hosted by propyllitized andesites of the Štiavnica stratovolcano was described from Hodruša-Hámre and Nová Baňa sites [73-75]. The paragenetic situation is very similar to those observed in this study, mostly including the wide variability in As/Sb ratios of the tetrahedrite group minerals, proustite-pyrargyrite series, and polybasite-pearceite series. However, the observed Se contents are generally low in ore minerals (up to $0.42 \mathrm{wt} \%$ in proustite, $0.22 \mathrm{wt} \%$ in tennantite, and 1.9 at. \% in acanthite; data from Nová Baňa only). The origin of uytenbogaardtite and acanthite, occurring in similar textural position to our samples, is however interpreted in terms of late superimposed (namely supergene) enrichment at both sites [73,75]. In our material, this interpretation is not probable at least in case of acanthite, which is usually Se-rich and often even alternated in the same paragenetic position by aguilarite or naumannite which are invariably characterized as hypogene hydrothermal phases [76].

\subsection{Origin of the Studied Mineralization}

Koděra et al. [23,74] and Majzlan et al. [75,76] characterized the formation conditions of paragenetically similar but Se-poor low-sulphidation Ag-Au mineralization occurring at the Kremnica, Hodruša-Hámre, and Nová Baňa sites on the basis of fluid inclusion and stable isotope studies. Authors interpreted the source of fluids in a mixture of meteoric and magmatic waters. Most of the present fluid inclusions show low salinities of aqueous fluids ( 0.5 to $5 \mathrm{wt} \% \mathrm{NaCl}$ eq.), which could be increased locally up to the $24 \mathrm{wt}$ $\% \mathrm{NaCl}$ eq. due to the boiling of fluids. The ore mineralization was deposited mostly at temperatures between ca. $\sim 270$ to $190{ }^{\circ} \mathrm{C}$, locally at lower temperatures down to $\sim 160{ }^{\circ} \mathrm{C}$.

The abovementioned formation temperatures can be adopted also in case of the Se-rich mineralization under this study, as is indicated from the chemical composition of some ore minerals. The observed As content in miargyrite (up to $0.23 \mathrm{apfu}$ ) requires formation temperatures between 200 and $350{ }^{\circ} \mathrm{C}$ [45]. Similarly, the observed complete miscibility between pyrargyrite and proustite indicates temperatures above $200-300{ }^{\circ} \mathrm{C}[45,46]$.

The crystallization of native silver followed by acanthite/aguilarite/naumannite requires an increase in the fugacity of sulphur, selenium, or both, as is indicated from $f S_{2}-f \mathrm{Se}_{2}$ diagram (Figure 26). The diagonal evolutionary trend is characteristic for epithermal ore deposits [34]. The close position of the boundaries of stability of the pairs acanthite-naumannite and galena-clausthalite in the same plot (Figure 26) well explains the observed common spatial association of minerals from both compositional series. The character of the discovered selenium mineralization indicates the formation from hydrothermal fluids with $f \mathrm{O}_{2}$ slightly above or close to the hematite-magnetite buffer and a $f \mathrm{Se}_{2} / f \mathrm{~S}_{2}$ ratio close to unity. The presence of minerals of galena-clausthalite solid solution show that the upper values of the $f \mathrm{Se}_{2} / f \mathrm{~S}_{2}$ ratio were more likely controlled by the galena-clausthalite buffer, which is still close to unity $[33,34]$. The occurrence of naumannite and acanthite which was deposited together with silver and Ag-sulphosalts requires conditions close to the native Ag-naumannite + acanthite invariant points [34,77]. Together with observed minerals of the galena-clausthalite series, it is possible to define a range of $\log f_{\mathrm{Se} 2}$ of the parent fluids between -18 and -25 and $\log f \mathrm{~S}_{2}$ between -15 and -20 , respectively $[34,77]$. These values correspond very well with conditions published for selenide-bearing $\mathrm{Au}-\mathrm{Ag}$ epithermal deposits [34]. 


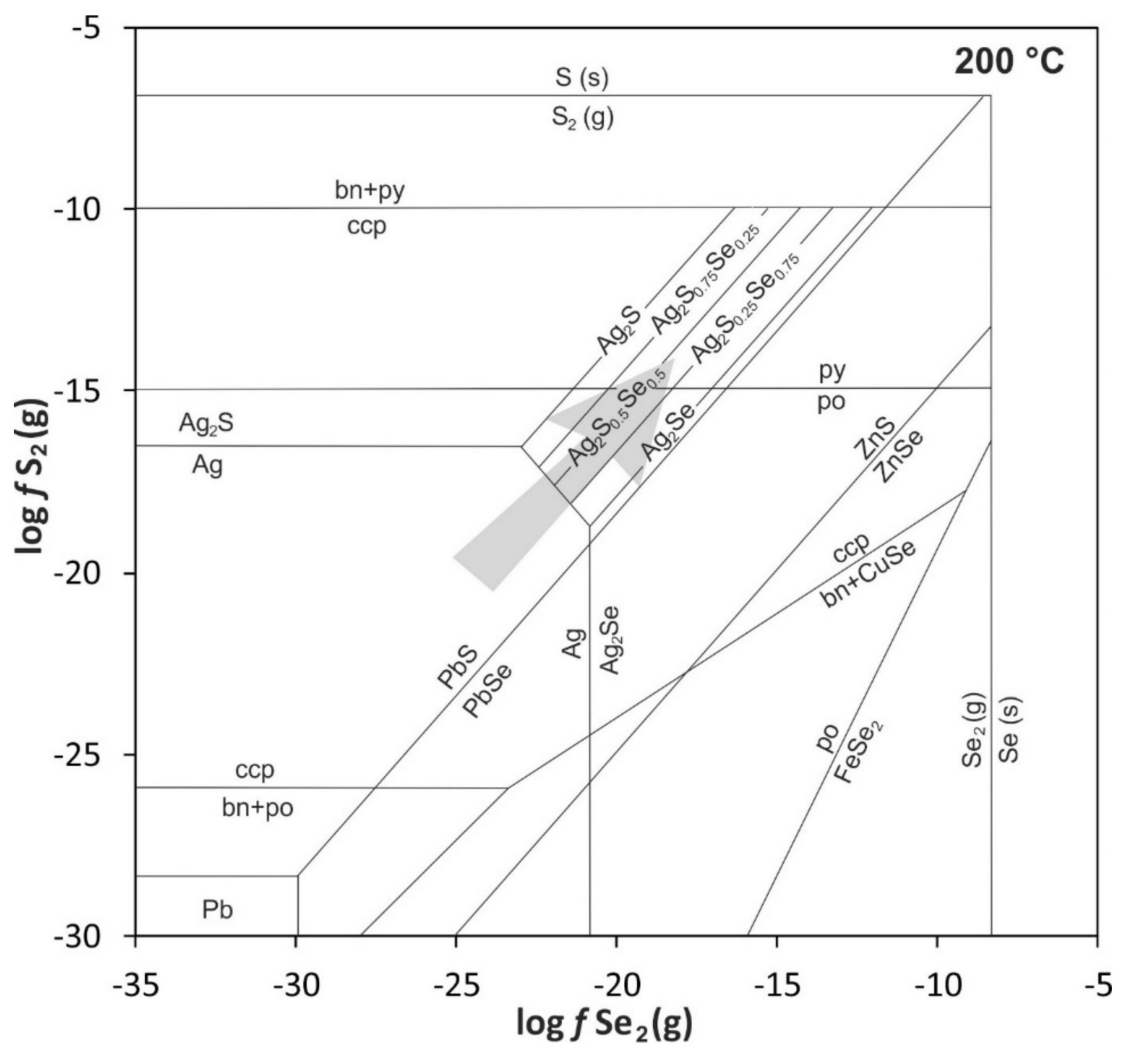

Figure 26. The $f S_{2}$ versus $f \mathrm{Se}_{2}$ diagram showing the relative stability of sulphides and selenides at $200{ }^{\circ} \mathrm{C}$ (adopted with permission from Zhuravkova et al. [78]). Arrow indicates probable evolutionary trend during crystallization of the early portion of the studied precious-metal mineralization. Explanations: bn—bornite, ccp-chalcopyrite, po-pyrrhotite, py-pyrite.

\section{Conclusions}

(1) The previously unknown selenium minerals (clausthalite, naumannite, aguilarite, selenopolybasite, and "selenopearceite") and increased selenium contents in $\mathrm{Ag}-\mathrm{Sb}(-\mathrm{As}), \mathrm{Ag}-\mathrm{Cu}$, $\mathrm{Ag}-\mathrm{Pb}$, and $\mathrm{Pb}-\mathrm{Sb}$ sulphosalts were determined in a hydrothermal quartz-dolomite vein from the Václav-south adit. This vein belongs to veins of the central part of the 1st vein system of the historical gold deposit in Kremnica. The observed contents of Se in suphosalts belong to the highest ever found worldwide.

(2) A suite of more than twenty Ag-bearing minerals were determined in samples from the studied vein: minerals of the $\mathrm{Au}-\mathrm{Ag}$ solid solution, acanthite, aguilarite, naumannite, uytenbogaardtite, $\mathrm{Ag}-\mathrm{Sb}(-\mathrm{As})$ sulphosalts (miargyrite, pyrargyrite, proustite), $\mathrm{Ag}-\mathrm{Cu}$ sulphosalts (Ag-rich tetrahedrite, freibergite, Ag-rich tennantite, argentotennantite, polybasite, pearceite, selenopolybasite, "selenopearceite"), and Ag-Pb sulphosalts (diaphorite, andorite VI, andorite IV, Ag-excess fizélyite, freieslebenite). The rare $\mathrm{Pb}-\mathrm{Sb}$ sulphosalts (scainiite, plagionite, robinsonite) were also identified at the studied occurrence.

(3) Besides observed $\mathrm{SeS}_{-1}$ substitution, a wide range of $\mathrm{AsSb}_{-1}$ substitutions was characteristic for the studied mineral association: complete solid solutions between proustite-pyrargyrite, polybasite-pearceite, tetrahedrite-tennantite, and freibergite-argentotennantite were confirmed.

(4) Similarly, to the whole Kremnica deposit, the studied hydrothermal vein is a typical example of low-sulphidation epithermal Ag-Au mineralization. The mineralization of the Kremnica deposit was formed from low-salinity fluids composed of a mixture of meteoric and magmatic waters at temperatures mostly between ca. $\sim 270$ to $190{ }^{\circ} \mathrm{C}$. These temperatures are in agreement with observed high contents of As in miargyrite and complete miscibility between pyrargyrite and proustite. 
(5) The described association of selenides and other Se-bearing mineral phases indicates hydrothermal fluids with $f_{\mathrm{O} 2}$ slightly above or close to the hematite-magnetite buffer. The $\log f_{\mathrm{Se} 2}$ of parent hydrothermal fluid probably ranged between -18 and -25 and $\log f_{\mathrm{S} 2}$ varied between -15 and -20 . These values correspond very well with conditions published for selenide-bearing $\mathrm{Au}-\mathrm{Ag}$ epithermal deposits.

Supplementary Materials: The following are available online at http:/ /www.mdpi.com/2075-163X/8/12/572/ s1: Table S1: Chemical composition of members of the clausthalite (cla)-galena (gal) solid solution, Table S2: Chemical composition of mineral phases along the $\mathrm{Ag}_{2} \mathrm{~S}-\mathrm{Ag}_{2} \mathrm{Se}$ join, Table S3: Chemical composition of members of the gold (gol)-silver (sil) solid solution, Table S4: Chemical composition of uytenbogaardtite, Table S5: Chemical composition of miargyrite, Table S6: Chemical composition of members of proustite (pro)-pyrargyrite (pyr) solid solution, Table S7: Chemical composition of tetrahedrite, Table S8: Chemical composition of freibergite, Table S9: Chemical composition of tennantite, Table S10: Chemical composition of argentotennantite, Table S11: Chemical composition of polybasite, Table S12: Chemical composition of selenopolybasite, Table S13: Chemical composition of pearceite, Table S14: Chemical composition of "selenopearceite", an unnamed Se-analogue of pearceite, Table S15: Chemical composition of diaphorite, Table S16: Chemical composition of andorite VI, Table S17: Chemical composition of andorite IV, Table S18: Chemical composition of Ag-excess fizélyite, Table S19: Chemical composition of freieslebenite, Table S20: Chemical composition of scainiite, Table S21: Chemical composition of plagionite, Table S22: Chemical composition of robinsonite.

Author Contributions: M.Š. and P.Š. found the mineralogical samples. J.S. and Z.D. conducted the WDS analyses and M.S.., J.S., and Z.D. wrote the paper.

Funding: The research was financially supported by the Ministry of Culture of the Czech Republic (DKRVO 2018/02; National Museum 00023272).

Acknowledgments: Referees as well as academic editor Hans-Jürgen Förster are acknowledged for comments and suggestions that helped to improve the early version of the manuscript.

Conflicts of Interest: The authors declare no conflict of interest.

\section{References}

1. Řídkošil, T.; Skála, R.; Johan, Z.; Šrein, V. Telluronevskite, Bi $\mathrm{Bi}_{3} \mathrm{TeSe}_{2}$, a new mineral. Eur. J. Mineral. 2001, 13, 177-185. [CrossRef]

2. Skála, R.; Ondruš, P.; Veselovský, F.; Táborský, Z.; Ďud'a, R. Vihorlatite, $\mathrm{Bi}_{24} \mathrm{Se}_{17} \mathrm{Te}_{4}$, a new mineral of the tetradymite group from Vihorlat Mts., Slovakia. Eur. J. Mineral. 2007, 19, 255-265. [CrossRef]

3. Bálintová-Števková, T.; Števko, M.; Ozdín, D.; Bakos, F. Pilsenite from Poruba pod Vihorlatom, Vihorlatské vrchy Mts. (Slovak Republic). Bull. Mineral.-Petrolog. Odd. Nár. Muz. (Praha) 2014, 22, 308-310. (In Slovak)

4. Peterec, D. Selenium and tellurium mineralization from Smolník. Nat. Carpat. 1996, 27, 53-62. (In Slovak)

5. Pršek, J.; Peterec, D. Bi-Se-Te mineralization from Úhorná (Spišsko Gemerské Rudohorie Mts., Slovakia): A preliminary report. Mineralogia 2008, 39, 87-103. [CrossRef]

6. Kozub, G.; Budzyń, B.; Pršek, J. Hydrothermal copper-bismuth mineralization from the Joremeny adit, Dobšiná, Slovak Republic_Preliminary report. Mineral. Spec. Pap. 2011, 38, 123-124.

7. Rojkovič, I. Uranium mineralization in Slovakia. Acta Geol. Univ. Comen. Monogr. Ser. 1997, 1-117.

8. Ragan, M.; Caňo, F. The first data on two new sulphosalts (CuPbSbBi and Ag-PbBiSb) containg selenium from the talc deposit of Hnúšt'a. Mineral. Slovak. 1991, 23, 368. (In Slovak)

9. Mat'o, L'; Ragan, M. Silver-bearing galena and Se-galena in assemblage with Ag minerals in the area of Kremnica and Hnúšt'a. In Stříbrné minerální asociace v Československu; DT, Ústí nad Labem, ČSVTS: Donovaly, Slovakia, 1992; pp. 109-115. (In Slovak)

10. Jeleň, S. Naumannite-First selenide in ores of the Štiavnica-Hodruša Ore Field. Mineral. Slovak. 1994, 26, 63-66. (In Slovak)

11. Mat'o, L'.; Háber, M. A new mineral assemblage in the Kremnica Ore Field. Mineral. Slovak. 1990, 22, 383-384. (In Slovak)

12. Mat'o, L'. Ag-Bi and Se galena in epithermal Au-Ag veins in the northern part of the Kremnica Ore Field. Mineral. Slovak. 1992, 24, 285-292. (In Slovak)

13. Lexa, J.; Halouzka, R.; Havrila, M.; Hanzel, L.; Kubeš, P.; Liščák, P.; Hojstričová, V. Explanatory Notes to the Geological Map of the Kremnické Vrchy Mountain Range; D. Štúr Institute of Geology: Bratislava, Slovakia, 1998; 308p. 
14. Kraus, I.; Chernishev, I.V.; Šucha, V.; Kovalenker, V.A.; Lebedev, V.A.; Šamajová, E. Use of illite for K/Ar dating of hydrothermal precious and base metal mineralization in Central Slovak Neogene volcanic rocks. Geol. Carpath. 1999, 50, 353-364.

15. Böhmer, M. Geology and mineral associations of gold-bearing veins in the central part of the Kremnica ore field. Acta Geol. Geogr. Univ. Comen. Geol. 1966, 11, 5-123. (In Slovak)

16. Lexa, J.; Bartalský, B. Low-sulfidation epithermal gold at Kremnica. In Epithermal Mineralization of the Western Carphatians; Molnár, F., Lexa, J., Hedenquist, J.W., Eds.; Society of Economic Geologists, Guidebook Series; Society of Economic Geologists: Littleton, CO, USA, 1999; Volume 31, pp. 265-273.

17. Koděra, P.; Lexa, J. Classic localities in Central Slovakia Volcanic Field: Gold, silver and base metal mineralizations and history at Banská Štiavnica and Kremnica. Acta Mineral. Petrogr. Field Guide Ser. 2010, 29, 18.

18. Böhmer, M. Deep Structures of the Kremnica ore Field; Open File Report; Geofond, ŠGÚDŠ: Bratislava, Slovakia, 1977. (In Slovak)

19. Mat'o, L'. Mineralogical Report of the Project Kremnica-Horná Ves, Exploration, Au-Ag Ores; Open File Report; Geofond, ŠGÚDŠ: Bratislava, Slovakia, 1997. (In Slovak)

20. Mat'o, L'.; Háber, M.; Knésl, J. Occurrence of Te minerals in the Kremnica Ore Field. Mineral. Slovka. 1987, 19, 457-467. (In Slovak)

21. Mat'o, L'. Minerals of the tetrahedrite-tennantite-goldfieldite series from Kremnica. Mineral. Slovka. 1994, 26, 433-444. (In Slovak)

22. Kraus, I.; Šamajová, E.; Šucha, V.; Lexa, J.; Hroncová, Z. Diagenetic and hydrothermal alterations of volcanic rocks into clay minerals and zeolites (Kremnické vrchy Mts., Western Carpathians). Geol. Carpath. 1994, 45, 151-158.

23. Koděra, P.; Šucha, V.; Lexa, J.; Fallick, A.E. The Kremnica Au-Ag epithermal deposit: An example of laterally outflowing hydrothermal system? In Digging Deeper, Proceedings of IX. SGA Conference, Dublin, Ireland, 1 January 2007; Andrew, C.J., et al., Eds.; Irish Association for Economic Geology: Dublin, UK, 2007; pp. 173-176.

24. Pouchou, J.L.; Pichoir, F. "PAP" ( $\left(\begin{array}{ll}\rho \mathrm{Z}\end{array}\right)$ procedure for improved quantitative microanalysis. In Microbeam Analysis; Armstrong, J.T., Ed.; San Francisco Press: San Francisco, CA, USA, 1985; pp. 104-106.

25. Simpson, D.R. The binary system PbS-PbSe. Econ. Geol. 1964, 59, 150-153. [CrossRef]

26. Wright, H.D.; Barnard, W.M.; Halbig, J.B. Solid solution in the system ZnS-ZnSe and PbS-PbSe at $300{ }^{\circ} \mathrm{C}$ and above. Am. Mineral. 1965, 50, 1802-1815.

27. Liu, H.; Chang, L.L.Y. Phase relation in the system PbS-PbSe-PbTe. Mineral. Mag. 1994, 58, 567-578. [CrossRef]

28. Coleman, R.G. The natural occurrence of galena-Clausthalite solid solution. Am. Mineral. 1959, 44, $166-174$.

29. Förster, H.J. Mineralogy of the U-Se-polymetallic deposit Niederschlema-Alberoda, Erzgebirge, Germany. IV. The continuous clausthalite-galena solid-solution series. N. Jb. Mineral. Abh. 2005, 181, 125-134. [CrossRef] [PubMed]

30. Sejkora, J.; Škácha, P. Selenides from fluorite deposit at Moldava in the Krušné hory Mts. (Czech Republic). Bull. Mineral.-Petrolog. Odd. Nár. Muz. (Praha) 2015, 23, 229-241. (In Czech)

31. Sejkora, J.; Škácha, P. Occurrence of selenides at deposit Běstvina in the Železné hory Mts. (Czech Republic). Bull. Mineral.-Petrolog. Odd. Nár. Muz. (Praha) 2015, 23, 255-260. (In Czech)

32. Sejkora, J.; Šrein, V.; Šreinová, B.; Dolníček, Z. Selenide mineralization of the uranium deposit Potı̌čky in the Krušné hory Mts. (Czech Republic). Bull. Mineral. Petrolog. 2017, 25, 306-317. (In Czech)

33. Simon, G.; Essene, E.J. Phase relations among selenides, sulfides, tellurides, and oxides. I. Thermodynamic properties and calculated equilibria. Econ. Geol. 1996, 91, 1183-1208. [CrossRef]

34. Simon, G.; Kessler, S.E.; Essene, E.J. Phase relations among selenides, sulfides, tellurides, and oxides. II. Application to selenide-bearing ore deposits. Econ. Geol. 1997, 92, 468-484. [CrossRef]

35. Bindi, L.; Pingitore, N.E. On the symmetry and crystal structure of aguilarite, $\mathrm{Ag}_{4}$ SeS. Mineral. Mag. 2013, 77, 21-31. [CrossRef]

36. Pingitore, N.E.; Ponce, B.F.; Estrada, L.; Eastman, M.P.; Yuan, H.L.; Porter, L.C.; Estrada, G. Calorimetric analysis of the system $\mathrm{Ag}_{2} \mathrm{~S}-\mathrm{Ag}_{2} \mathrm{Se}$ between 25 and $250{ }^{\circ} \mathrm{C}$. J. Material. Res. 1993, 8, 3126-3130. [CrossRef]

37. Pal'yanova, G.A.; Chudnenko, K.V.; Zhuravkova, T.V. Thermodynamic properties of solid solutions in the system $\mathrm{Ag}_{2} \mathrm{~S}-\mathrm{Ag}_{2} \mathrm{Se}$. Thermochim. Acta 2014, 575, 90-96. [CrossRef] 
38. Kullerud, K.; Kotková, J.; Šrein, V.; Drábek, M.; Škoda, R. Solid solution in the system acanthite $\left(\mathrm{Ag}_{2} \mathrm{~S}\right)$ - Naumannite $\left(\mathrm{Ag}_{2} \mathrm{Se}\right)$ and the relationships between $\mathrm{Ag}$-sulfoselenides and Se-bearing polybasite from the Kongsberg silver district, Norway, with implications for sulfur-selenium fractionation. Contr. Mineral. Petrol. 2018, 173, 71. [CrossRef]

39. Pal'yanova, G.A.; Kravtsova, R.G.; Zhuravkova, T.V. $\mathrm{Ag}_{2}(\mathrm{~S}, \mathrm{Se})$ solid solutions in the ores of the Rogovik gold-silver deposit (northeastern Russia). Russ. Geol. Geophys. 2015, 56, 1738-1748. [CrossRef]

40. Pal'yanova, G.A.; Savva, N.E. Some sulfides of gold and silver: Composition, mineral assemblage, and conditions of formation. Theor. Found. Chem. Eng. 2008, 42, 749-761. [CrossRef]

41. Proskurnin, V.F.; Palyanova, G.A.; Karmanov, N.S.; Bagaeva, A.A.; Gavrish, A.V.; Petrushkov, B.S. The first discovery of uytenbogaardtite in Taimyr (Konechnoe ore occurrence). Dokl. Earth Sci. 2011, 441, 1661-1665. [CrossRef]

42. Pažout, R.; Sejkora, J.; Šrein, V. Ag-Pb-Sb sulphosalts and Se mineralization of the St. Antony de Padua mine at Poličany-Model example of the mineralization of silver lodes in the historic Kutná Hora $\mathrm{Pb}-\mathrm{Zn}-\mathrm{Ag}$ ore district (Czech Republic). Minerals 2018. submitted.

43. Yunfen, L.; Yueying, L.; Mingming, Y.; Kuishou, D.; Naijue, Z.; Fang, G. Selenian miargyrite-A new variety of miargyrite. Geol. Rev. 1990, 1, 001. (In Chinese)

44. Nekrasov, I.Y.; Lunin, S.Y. Formation conditions of silver sulfides, selenides, and sulfoselenides in the system Ag-Sb-S-Se, determined experimentally. Miner. Zhurnal 1987, 9, 25-39. (In Russian)

45. Ghosal, S.; Sack, R.O. As-Sb energetics in argentian sulfosalts. Geochim. Cosmochim. Acta 1995, 59, $3573-3579$. [CrossRef]

46. Toulmin, P. Proustite-pyragyrite solid solution. Am. Mineral. 1963, 48, 725-736.

47. Ondruš, P.; Veselovský, F.; Gabašová, A.; Hloušek, J.; Šrein, V.; Vavřín, I.; Skála, R.; Sejkora, J.; Drábek, M. Primary minerals of the Jáchymov ore district. J. Czech Geol. Soc. 2003, 48, 19-147.

48. Moëlo, Y.; Makovicky, E.; Mozgova, N.N.; Jambor, J.L.; Cook, N.; Pring, A.; Paar, W.; Nickel, E.H.; Graeser, S.; Karup-Møller, S.; et al. Sulfosalt systematics: A review report of the sulfosalt sub-committee of the IMA Commission on Ore Mineralogy. Eur. J. Mineral. 2008, 20,7-46. [CrossRef]

49. Rozhdestvenskaya, I.V.; Zayakina, N.V.; Samusikov, V.P. Crystal structure features of minerals from the tetrahedrite-freibergite series. Mineral. Zhurnal 1993, 15, 9-17. (In Russian)

50. Spiridonov, E.M.; Sokolova, N.F.; Gapeev, A.K.; Dashevskaya, D.M.; Evstingeeva, T.L.; Chvileva, T.N.; Demidov, V.G.; Balashov, E.P.; Shul'ga, V.I. A new mineral-argentotennantite. Dokl. Akad. Nauk SSSR 1986, 290, 206-210. (In Russian)

51. Kalbskopf, R. Strukturverfeinerung des Freibergits. Tschermaks Min. Petr. Mitt. 1972, 18, 147-155. [CrossRef]

52. Riley, J.F. The tetrahedrite-freibergite series, with reference to the Mount Isa $\mathrm{Pb}-\mathrm{Zn}-\mathrm{Ag}$ orebody. Miner. Depos. 1974, 9, 117-124. [CrossRef]

53. Zakrzewski, M.A. Members of the freibergite-argentotennantite series and associated minerals from Silvermines, County Tipperary, Ireland. Min. Mag. 1989, 53, 293-298. [CrossRef]

54. Hatert, F.; Burke, E.A.J. The IMA-CNMNC dominant-constituent rule revisited and extended. Can. Mineral. 2008, 46, 717-728. [CrossRef]

55. Bindi, L.; Evain, M.; Spry, P.G.; Menchetti, S. The pearceite-polybasite group of minerals: Crystal chemistry and new nomenclature rules. Am. Mineral. 2007, 92, 918-925. [CrossRef]

56. Bindi, L.; Evain, M.; Menchetti, S. Selenopolybasite, $\left[(\mathrm{Ag}, \mathrm{Cu})_{6}(\mathrm{Sb}, \mathrm{As})_{2}(\mathrm{~S}, \mathrm{Se})_{7}\right]\left[\mathrm{Ag}{ }_{9} \mathrm{Cu}(\mathrm{S}, \mathrm{Se})_{2} \mathrm{Se}{ }_{2}\right]$, a new member of the pearceite-polybasite group from the De Lamar mine, Owyhee County, Idaho, USA. Can. Mineral. 2007, 45, 1525-1528. [CrossRef]

57. Evain, M.; Bindi, L.; Menchetti, S. Structure and phase transition of the Se-rich variety of antimonpearceite, $\left[(\mathrm{Ag}, \mathrm{Cu})_{6}(\mathrm{Sb}, \mathrm{As})_{2}(\mathrm{~S}, \mathrm{Se})_{7}\right]\left[\mathrm{Ag}_{9} \mathrm{Cu}(\mathrm{S}, \mathrm{Se})_{2} \mathrm{Se}_{2}\right]$. Acta Cryst. Sect. B 2006, 62, 768-774. [CrossRef]

58. Bindi, L.; University of Florence, Italy. Personal communication, 2018.

59. Mozgova, N.N.; Efimov, A.V.; Nenasheva, S.N.; Golovanova, T.I.; Sivtsov, A.V.; Tsepin, A.I.; Dobretsova, I.G. New data on diaphorite and brogniardite. Zap. Vsesoyuz. Mineral. Obshsch. 1989, 118, 47-63. (In Russian)

60. Cook, N.J.; Damian, G.S. New data on "plumosite" and other sulphosalt minerals from the Herja hydrothermal vein deposit, Baia Mare district, Rumania. Geol. Carpath. 1997, 48, 387-399.

61. Frizzo, P.; Simone, S. Diaphorite in the Pollone ore deposit (Apuan Alps-Tuscany, Italy). Eur. J. Mineral. 1995, 7,705-708. [CrossRef] 
62. Hoffman, V.; Trdlička, Z.; Hulínský, V.; Langrová, A.; Arnoldová, V. Mineralogisch-chemisches Studium des Diaphorits von Kutná Hora (ČSSR). Chem. Erde 1977, 36, 36-44.

63. Sejkora, J.; Litochleb, J.; Zemek, V. Contribution to the chemical composition of ore minerals from the southern part of the Kutná Hora Ore District. Bull. Mineral.-Petrolog. Odd. Nár. Muz. (Praha) 2002, 10, 283-289.

64. Armbruster, T.; Makovicky, E.; Berlepsch, P.; Sejkora, J. Crystal structure, cation ordering, and polytypic character of diaphorite, $\mathrm{Pb}_{2} \mathrm{Ag}_{3} \mathrm{Sb}_{3} \mathrm{~S}_{8}$, a PbS-based structure. Eur. J. Mineral. 2003, 15, 137-146. [CrossRef]

65. Ito, T.I.; Muraoka, H. Nakaseite, an andorite-like new mineral. Ztschr. Kristallogr. 1960, 113, 94-98. [CrossRef]

66. Moëlo, Y.; Makovicky, E.; Karup-Moller, S. Sulfures complexes plombo-argentifères: Minéralogie et cristallochimie de la série andorite-fizelyite. Doc. BRGM 1989, 167, 1-107.

67. Spiridonov, E.M.; Petrova, I.V.; Dashevskaya, D.; Balashov, E.P.; Klimova, L.M. Roshchinite $\mathrm{Ag}_{19} \mathrm{~Pb}_{10} \mathrm{Sb}_{51} \mathrm{~S}_{96}$-A new mineral. Dokl. Akad. Nauk SSSR 1990, 312, 197-200.

68. Makovicky, E.; Stöger, B.; Topa, D. The incommensurately modulated crystal structure of roshchinite, $\mathrm{Cu}_{0.09} \mathrm{Ag}_{1.04} \mathrm{~Pb}_{0.65} \mathrm{Sb}_{2.82} \mathrm{As}_{0.37} \mathrm{~S}_{6.08}$. Ztschr. Kristallogr. Cryst. Mater. 2018, 233, 255-267. [CrossRef]

69. Plášil, J.; Sejkora, J.; Litochleb, J.; Goliáš, V. Discovery of an andorite-like mineral (so called "minéral $F^{\prime \prime}$ ) associated with diaphorite and other $\mathrm{Pb}-\mathrm{Ag}-\mathrm{Sb}$ phases in dump of the Lill mine (Černojamské deposit), Př́ibram. Bull. Mineral.-Petrolog. Odd. Nár. Muz. (Praha) 2005, 13, 187-192. (In Czech)

70. Yang, H.; Downs, R.T.; Burt, J.B.; Costin, G. Structure refinement of an untwinned single crystal of Ag-excess fizelyite, $\mathrm{Ag}_{5.94} \mathrm{~Pb}_{13.74} \mathrm{Sb}_{20.84} \mathrm{~S}_{48}$. Can. Mineral. 2009, 47, 1257-1264. [CrossRef]

71. Orlandi, P.; Moelo, Y.; Meerschaut, A.; Palvadeau, P. Lead-antimony sulfosalts from Tuscany (Italy); I, Scainiite, $\mathrm{Pb}_{14} \mathrm{Sb}_{30} \mathrm{~S}_{54} \mathrm{O}_{5}$, the first Pb-Sb oxy-sulfosalt, from Buca della Vena Mine. Eur. J. Mineral. 1999, 11, 949-954. [CrossRef]

72. White, N.C.; Hedenquist, J.W. Epithermal gold deposits: Styles, characteristics and exploration. SEG Newsl. 1995, 23, 9-13.

73. Majzlan, J. Ore mineralization at the Rabenstein occurrence near Banská Hodruša, Slovakia. Mineral. Slovak. 2009, 41, 45-54.

74. Koděra, P.; Lexa, J.; Fallick, A.E.; Wälle, M.; Biroň, A. Hydrothermal fluids in epithermal and porphyry Au depositsin the Central Slovakia Volcanic Field. Geol. Soc. Lond. Spec. Publ. 2014, 402, 177-206. [CrossRef]

75. Majzlan, J.; Berkh, K.; Koděra, P.; Števko, M.; Bakos, F.; Milovský, R. A mineralogical, fluid inclusion, and isotopic study of selected epithermal Ag-Au occurrences in the Banská Štiavnica-Hodruša-Hámre ore district, Western Carpathians. Acta Geol. Slovka. 2016, 8, 133-147.

76. Majzlan, J.; Berkh, K.; Kiefer, S.; Koděra, P.; Fallick, A.E.; Chovan, M.; Bakos, F.; Biroň, A.; Ferenc, Š.; Lexa, J. Mineralogy, alteration patterns, geochemistry, and fluid properties of the Ag-Au epithermal deposit Nová Baňa, Slovakia. Mineral. Petrol. 2018, 112, 1-23. [CrossRef]

77. Anthony, J.W.; Bideaux, R.A.; Bladh, K.W.; Nichols, M.C. Handbook of Mineralogy, Vol. 1. Elements, Sulfides, Sulfosalts; Mineral Data Publishing: Tucson, AZ, USA, 1990.

78. Zhuravkova, T.V.; Palyanova, G.A.; Kravtsova, R.G. Physicochemical formation conditions of silver sulfoselenides at the Rogovik deposit, Northeastern Russia. Geol. Ore Depos. 2015, 57, 313-330. [CrossRef]

(c) 2018 by the authors. Licensee MDPI, Basel, Switzerland. This article is an open access article distributed under the terms and conditions of the Creative Commons Attribution (CC BY) license (http:// creativecommons.org/licenses/by/4.0/). 